\title{
A Manual on Fire Assaying and Determination of the Noble Metals in Geological Materials
}

$\mathbb{G} \mathbb{E} \mathbb{O} \mathbb{O} \mathbb{G} \mathbb{C} \mathbb{A} \quad S \mathbb{U} \mathbb{R} \mathbb{Y} \quad \mathbb{B} \mathbb{U} \mathbb{L} \mathbb{E} \mathbb{T} \mathbb{N} \quad \mathbb{1} 4 \mathbb{4} 5$

QE 75

B9

no. 1445 
$\because \cdots$ 


\section{A Manual on Fire Assaying and Determination of the Noble Metals in Geological Materials}

By JOSEPH HAFFTY, L. B. RILEY, and W. D. GOSS

G E O L O G I C A L

Detailed description of techniques and methods of analysis

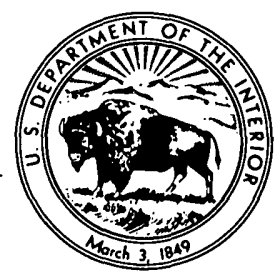




\section{UNITED STATES DEPARTMENT OF THE INTERIOR}

CECIL D. ANDRUS, Secretary

\section{GEOLOGICAL SURVEY}

V. E. McKelvey, Director

Library of Congress Cataloging in Publication Data

Haffty, Joseph

A manual on fire assaying and determination of the noble metals in geological materials.

(Geological Survey Bulletin 1445)

Bibliography: p. 56

Supt. of Docs. no.: I 19.3:1438

1. Gold-Analysis. 2. Silver-Analysis. 3. Platinum group-Analysis.

I. Riley, Leonard Benjamin, joint author. II. Goss, W. D., joint author. III. Title: A manual on fire assaying and determination of the noble metals in geological materials.

IV. United States Geological Survey Bulletin 1445.

QE75.B9 no. 1445 [QE516.A9] 557.3'08s [669'.96'2] 77-608100

For sale by the Superintendent of Documents, U.S. Government Printing Office Washington, D.C. 20402

Stock No. 024-001-03021-7 


\section{CONTENTS}

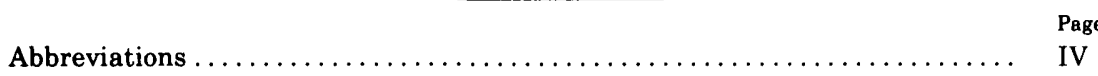

Units of measure and their equivalents $\ldots \ldots \ldots \ldots \ldots \ldots \ldots \ldots \ldots \ldots, \mathrm{V}$

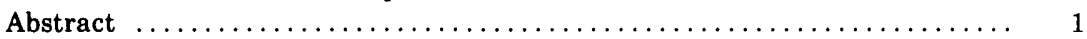

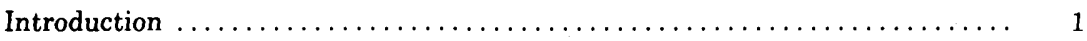

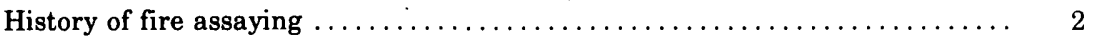

History of fire assaying in the U.S. Geological Survey $\ldots \ldots \ldots \ldots \ldots \ldots \ldots$

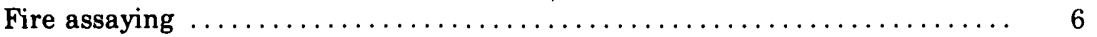

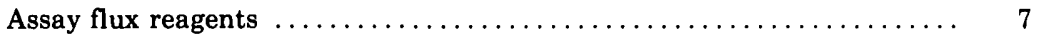

Selection of flux components $\ldots \ldots \ldots \ldots \ldots \ldots \ldots \ldots \ldots \ldots \ldots \ldots \ldots \ldots \ldots \ldots$

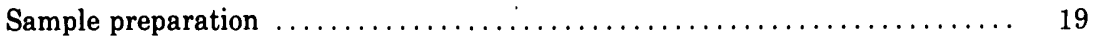

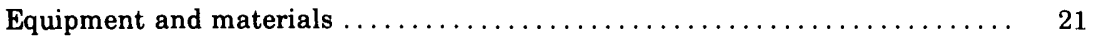

Weighing the components $\ldots \ldots \ldots \ldots \ldots \ldots \ldots \ldots \ldots \ldots \ldots \ldots \ldots \ldots \ldots \ldots 23$

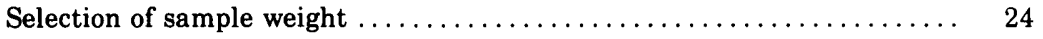

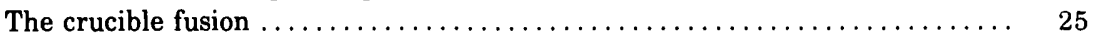

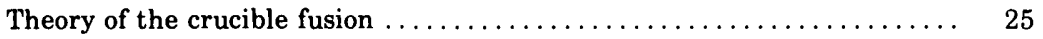

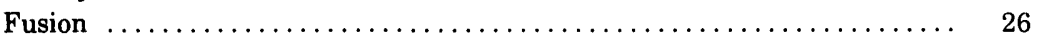

Fusion of chromite-bearing samples using an auxiliary flux ...... 31

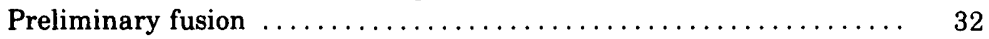

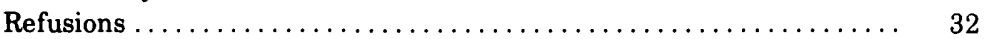

Fusion of used cupels $\ldots \ldots \ldots \ldots \ldots \ldots \ldots \ldots \ldots \ldots \ldots \ldots \ldots \ldots$

Cupellation $\ldots \ldots \ldots \ldots \ldots \ldots \ldots \ldots \ldots \ldots \ldots \ldots \ldots \ldots \ldots \ldots \ldots \ldots \ldots \ldots$

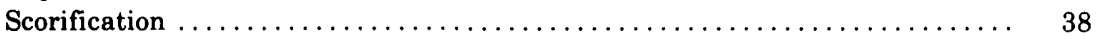

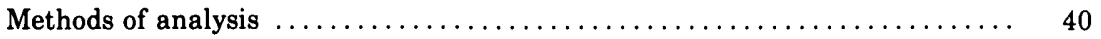

Determination of:

Gold by fire assay and atomic absorption $\ldots \ldots \ldots \ldots \ldots \ldots \ldots \ldots \ldots \ldots$

Gold by fire assay and neutron-activation analysis $\ldots \ldots \ldots \ldots \ldots \ldots \ldots$

Gold in phosphates by activation analysis using epithermal neutrons . . . . 44

Silver by acid digestion $\ldots \ldots \ldots \ldots \ldots \ldots \ldots \ldots \ldots \ldots \ldots \ldots \ldots \ldots \ldots \ldots$

Palladium, platinum, and rhodium by fire-assay preconcentration and emis-

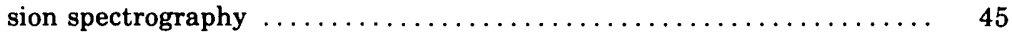

Platinum and palladium by fire-assay preconcentration and neutron-activation analysis

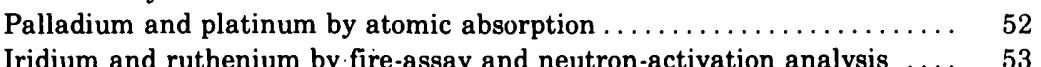

The noble metals and copper by a combination mini-fire-assay neutron-ac-

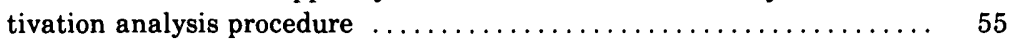

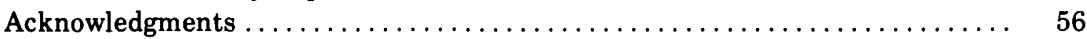

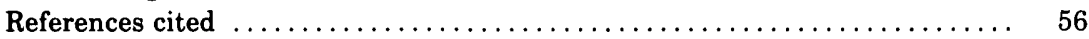




\section{ILLUSTRATIONS}

Figures 1-20. Photographs showing:

1. Grinding-room arrangement $\ldots \ldots \ldots \ldots \ldots \ldots \ldots \ldots, 19$

2. Some grinding-room equipment $\ldots \ldots \ldots \ldots \ldots \ldots \ldots, 20$

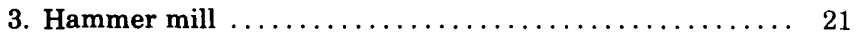

4. Some furnace-room equipment $\ldots \ldots \ldots \ldots \ldots \ldots \ldots \ldots, 22$

5. Furnace-room supplies $\ldots \ldots \ldots \ldots \ldots \ldots \ldots \ldots \ldots \ldots \ldots \ldots \ldots \ldots, 23$

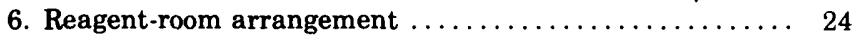

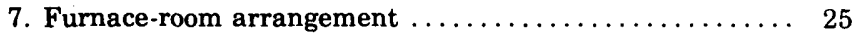

8. Heat protective equipment $\ldots \ldots \ldots \ldots \ldots \ldots \ldots \ldots \ldots, 26$

9. Furnace tools ........................... 27

10. Placing fireclay crucibles in furnace $\ldots \ldots \ldots \ldots \ldots \ldots 27$

11. Fireclay crucibles shown in furnace $\ldots \ldots \ldots \ldots \ldots \ldots, 28$

12. Melt being poured into iron mold $\ldots \ldots \ldots \ldots \ldots \ldots \ldots, 29$

13. Additional furnace tools $\ldots \ldots \ldots \ldots \ldots \ldots \ldots \ldots \ldots, 29$

14. Shaping lead button for cupellation $\ldots \ldots \ldots \ldots \ldots \ldots, 30$

15. Close-up view of lead buttons before and after shaping ... 31

16. Transferring buttons to hot cupels .............. 36

17. Technique of cupellation .................... 36

18. Cupels with beads ........................ 37

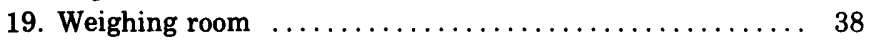

20. Scorification $\ldots \ldots \ldots \ldots \ldots \ldots \ldots \ldots \ldots \ldots \ldots \ldots, 39$

21. Flow diagram for noble metal and copper procedure ........ 56

\section{TABLES}

TABLE 1. Charges for various types of samples $\ldots \ldots \ldots \ldots \ldots \ldots \ldots \ldots \ldots, 11$

2. Size of scorifier versus weight of lead for a $25-30 \mathrm{~g}$ button........ 40

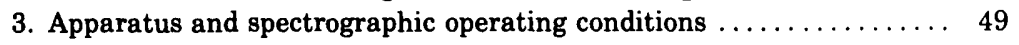

4. Iron lines used for plate calibration $\ldots \ldots \ldots \ldots \ldots \ldots \ldots \ldots \ldots 49$

5. Analytical lines used in determination of palladium, platinum, and rhodium $\ldots \ldots \ldots \ldots \ldots \ldots \ldots \ldots \ldots \ldots \ldots, 49$

\section{ABBREVIATIONS}

A or amps. . Amperes.

$\AA$......... Angstrom.

A.C.S. .... American Chemical

Society - A standard measurement equal to or exceeds that specified by a Committee of the American Chemical Society.
ASTM .... American Society for Testing and Materials - A designation of ASTM Committee E-2.

avdp ...... Avoirdupois.

bp ....... Boiling point.

${ }^{\circ} \mathrm{C}$........ Degrees Celsius.

cm ........ Centimeter.

d.c. ....... Direct current. 



\title{
A MANUAL ON FIRE ASSAYING AND DETERMINATION OF THE NOBLE METALS IN GEOLOGICAL MATERIALS
}

\author{
By Joseph Haffty, L. B. Riley, and W. D. Goss
}

\begin{abstract}
Detailed directions are given for use of fire-assay techniques to separate and concentrate the noble metals - $\mathrm{Ag}, \mathrm{Au}, \mathrm{Ir}, \mathrm{Os}, \mathrm{Pd}, \mathrm{Pt}, \mathrm{Rh}, \mathrm{Ru}$ - from many varieties of samples. Included are procedures for selecting appropriate assay charges based on approximate chemical compositions of the samples. Whenever such data are available, a saving of time by avoiding reruns is generally possible even with minimal mineralogical information. Also included are descriptions of methods currently being used by the U.S. Geological Survey for the determination of the various noble metals, mostly after concentration by fire assay.
\end{abstract}

\section{INTRODUCTION}

Fire assaying is an ancient form of quantitative chemical analysis by which metals are separated and determined in ores and metallurgical products with the aid of heat and dry reagents. At present, this technique is used principally to preconcentrate the noble metals from ores or metallurgical products. The object is to form a melt of at least two phases - a complex liquid borosilicate slag and a liquid lead phase of controlled size. The high degree of solubility of the noble metals in molten metallic lead plus the great difference in specific gravity between the lead and slag permit the separation of the noble metals from the slag as lead alloys. The subsequent removal of the lead as lead oxide in a porous vessel known as a cupel by a carefully controlled oxidizing fusion separates the lead from the noble metals. The metallic bead remaining is then analyzed for the noble metals.

For almost a century the U.S. Geological Survey has been engaged intermittently in the determination of the noble metals. Since 1966 the Survey has been intensely involved in the search for noble metals, and this involvement required the development and improvement of various methods for the determination of these metals. The methods 
commonly used combine fire assay with subsequent determination by atomic absorption spectroscopy, emission-spectrographic analysis, or neutron-activation analysis. An exception is the silver method which utilizes direct nitric acid extraction prior to its determination by atomic absorption.

This bulletin is to serve as a manual for the instruction of beginners in fire assaying and as a guide to chemists and technicians who are interested or involved in the determination of the noble metals. No attempt was made to include the extensive literature references on fire assaying or on methods for determining the noble metals. Only those techniques and methods developed and currently being used in laboratories of the U.S. Geological Survey are included in this compilation.

As the samples submitted to the U.S. Geological Survey are so varied in chemical and mineralogical composition, it seemed desirable to preserve the experimental observations of the personnel of the laboratories, especially in regard to the fluxes used. The section which lists the various types of ore or rock with their chemical composition also lists the flux components and the amount of each used.

The equipment used to perform the various functions of fire assaying are basic to the technique and have been used for many years. Other equipment, such as balances, are more modern in design and were selected for speed of operation. The equipment is illustrated and described in appropriate sections of this report.

\section{HISTORY OF FIRE ASSAYING}

The beginnings of fire assaying can be traced to the finds in Troy II (about 2600 B.C.) and in the Cappadocian Tablets (2250-1950 B.C.). These finds prove that very pure silver was made in the twenty-fifth. century B.C. From this evidence we must conclude that the cupellation process, and therefore fire assaying, was invented in Asia Minor in the first half of the third millennium B.C. shortly after the discovery of the manufacture of lead from galena (Forbes, 1950, p. 213). Theodore A. Wertime $(1973$, p. 883) wrote that the first convincing evidence of the production of silver from lead ores is the cupel buttons found at Mahmatlar in the late third millenium B.C. and that are now in the Hittite Museum in Ankara, Turkey.

Biblical references to the use of fire-assay techniques can be traced to the prophet Moses (about 1300 B.C.). Numbers 31: 22, $23^{1}$ states: "Only the gold, and the silver, the brass, the iron, the tin, and the lead, every thing that may abide the fire, ye shall make it go through the

I All Biblical references are to the King James Version (1611) unless otherwise indicated. 
fire, and it shall be clean: * * *." From David (about 1000 B.C.), Psalms 12: 7 (Dahood, 1966 p. 72) states:

"The promises of Yahweh (God)

are promises unalloyed, silver purged in a crucible, of clay refined seven times."

From Solomon (10th century B.C.) Proverbs 17: 3:

"The fining pot [cupel] is for silver and the furnace for gold:

but the Lord trieth the hearts."

References to the dross obtained in cupellation are contained in Proverbs 26: 23:

"Burning lips and a wicked heart are like a potsherd covered with silver dross."

From Jeremiah (born after 650, died 570 B.C.) 6: 29 (Bright, 1965 p. 47):

"The bellows blow fiercely,

But the lead comes whole from the fire.

It's useless to go on refining,

The wicked are not removed."

Zechariah (sixth century B.C.) 13: 9 states: "And I will bring the third part through the fire, and will refine them as silver is refined, and will try them as gold is tried: ${ }^{* * *}$." More reference is made to the "fining pot" (cupel) in Malachi (fifth century B.C.) 3: 3: "And he shall sit as a refiner and purifier of silver: and he shall purify the sons of Levi, and purge them as gold and silver, that they may offer unto the Lord an offering in righteousness."

These references are but a few that demonstrate the extent to which fire-assay techniques permeated Asia Minor in ancient times.

The Romans were able to desilver lead down to 0.01 percent or even to 0.002 percent in some cases and marked their cupelled desilvered lead "EX ARG." Roman lead pipe was found to be desilvered almost completely. In addition to the employment of fire-assay techniques for refining lead and silver, the Romans were the first to make extensive use of the amalgamation process. This process consisted of mixing the finely ground ore with salt, copper sulfate, and mercury and exposing the mixture to the air in heaps which were constantly worked. The silver-amalgam (silver-mercury compound) was then distilled, the mercury recovered as distillate, and the silver as residue (Forbes, 
1950, p. 208). Another version of the amalgamation process used by the Romans in treating rich gold ores consisted of crushing the ore and mixing it with mercury. The gangue was separated by forcing the mercury through leather, and then the amalgam (solution of the gold and silver in the mercury) was heated to recover the noble metals (Forbes, 1964, p. 173). The amalgamation processes were made possible because the Romans produced mercury on a large scale. The ore worked was cinnabar, crushed in sandstone mortars with stone pestles, and heated in furnaces where the mercury distilled off to collect in the fore-hearth.

With the fall of the Roman Empire by the invasions and conquests of the barbarian hordes, intellectual life stagnated for about 500 years. It is doubtful that any significant advancement in the art of fire assaying took place during that period. With the revival of learning in the latter centuries of the Middle Ages, the art of fire assaying was renewed vigorously. One man stands out above all in this period Agricola (1494 - 1555). In about 1529 he began to write "De $\mathbb{R e}$ Metallica" (1556), which he completed in 1550 but did not send to the publishers until 1553. Preparation of the woodcuts delayed publication until a year after the death of Agricola. In this book, Agricola, who was the first author to attempt to cover the subject of fire assaying in its entirety, arranged his material systematically. He described the tools and equipment to be used in assaying, stressed the quantitative aspects of each step, and for the first time gave instructions for assaying. "De $\operatorname{Re}$ Metallica" was definitely the first and foremost textbook on fire assaying, and it served as a guide to miners and metallurgists for the following 180 years.

Although some publications on fire assaying and metallurgy appeared in the sixteenth and seventeenth centuries following Agricola's "De Re Metallica," it was not until the first half of the eighteenth century that creditable works (for instance, C. A. Schluter's "Hutte-Werken, Braunshweig," published in 1738, cited by Hoover and Hoover in their translation of Agricola, 1556) began to supersede Agricola's book. Numerous publications on fire assaying, mining,and metallurgy followed in the 19 th and 20 th centuries. With continuing worldwide use and interest in the noble metals, one can confidently predict that fire-assay techniques will still be used in the future for the determination of the noble metals.

\section{MISTORY OF FIRE ASSAYING IN THE U.S. GEOLOGICAL SURVEY}

In 1879, Clarence King, the first Director of the newly-formed U.S. Geological Survey, instructed Samuel F. Emmons, geologist-in-charge, to undertake a detailed study of the geology and mining industry of 
Leadville, Colo. (Emmons, 1886, p. VII -XI). In 1880 Emmons was fortunate in securing the services of Antony Guyard, a former pupil of the École Des Mines, and, for 12 years, chemist at the well-known metallurgical works of Johnson \& Matthey, London. He was assigned to make chemical investigations of the processes of lead smelting used by numerous smelters at Leadville and vicinity.

Thus, in Denver, in 1880 (Emmons, 1886, p. 621) Guyard was the first in the U.S. Geological Survey to use fire assay as an analytical technique. W. F. Hillebrand was also employed in 1880 and, with Guyard, started a chemical laboratory in Denver. Guyard died in 1884. As a result of a general reorganization, Hillebrand was transferred to Washington, D.C., in 1885 (Clarke and Hillebrand, 1897). By 1888 the Survey's Denver laboratory was closed.

Although Hillebrand's major interests lay elsewhere, he had become sufficiently familiar with fire assaying and had the equipment necessary to investigate, with $\mathrm{E}$. T. Allen, the special steps needed for fire assaying of gold telluride ores (Hillebrand and Allen, 1905). The results of these investigations remain the basic study for gold telluride analysis. Their experiments, though extensive, suggested the need for additional work. However, the Washington quarters occupied by the Survey had become so crowded that the assay furnaces were dismantled, and assaying was abandoned altogether.

In 1948 there was a need to determine the gold and silver content of samples collected for uranium and thorium investigations, particularly in the Front Range of Colorado. Both the volume of this work and the security requirements of that time made it imperative for the Survey to do its own fire assaying. D. L. Skinner, who had joined the staff of the chemical laboratory in Denver, had had extensive fireassaying experience at the U.S. Mint in Denver. He supervised the purchase and installation of equipment and in 1951, after an interval of nearly 50 years, revived the use of fire assaying in the U.S. Geological Survey. The furnace was christened by baking a pan of biscuits in it before it was contaminated by lead.

Again, in 1966, investigations for the heavy-metals programs particularly those concerned with gold and the other noble metals encouraged the expansion of existing analytical techniques and the search for new ones. Some of the results are given in this manual. One interesting and important result is the combining of fire assaying with such techniques as atomic absorption, optical emission spectrography, and neutron-activation analysis. Thus, in one sense, the very oldest analytical method has been updated by combining it with the most modern techniques. 


\section{FIRE ASSAYING}

The advantage of using fire-assay techniques for the determination of the noble metals is the ability to use a relatively large ore sample from which to concentrate these metals, in addition to eliminating virtually all the associated gangue minerals. This is accomplished by employing dry reagents in proper proportions to the pulverized ore so that the mixture will fuse at an easily attained temperature (discussed later). The reagents generally used in combination with the sample are sodium carbonate $\left(\mathrm{Na}_{2} \mathrm{CO}_{3}\right)$, litharge $(\mathrm{PbO})$, silica $\left(\mathrm{SiO}_{2}\right)$, borax glass $\left(\mathrm{Na}_{2} \mathrm{~B}_{4} \mathrm{O}_{7}\right)$, and calcium fluoride $\left(\mathrm{CaF}_{2}\right)$, together with household flour as a reducing agent or potassium nitrate $\left(\mathbb{K N O}_{3}\right)$ as an oxidizing agent. These reagents in combination are referred to as the flus, and the flux plus the ore sample and any noble metal added constitute the "charge."

The chemical reactions which take place in an assay fusion are very complex and beyond the scope of this bulletin. Detailed treatment of the theory involved can be found in textbooks on fire assaying (Bugbee, 1940; Shepard and Dietrich, 1940). However, one must initially determine whether the ore is neutral, reducing, or oxidizing in character. Neutral ores have no reducing or oxidizing power and usually are the siliceous, oxide, and carbonate ores. Reducing ores decompose litharge to form metallic lead and usually consist of sulfides and carbonaceous matter. Oxidizing ores contain ferric oxide and manganese dioxide which, when fused with fluxes, oxidize lead or reducing agents. Ores with considerable oxidizing power are comparatively rare.

Fire assay is facilitated if the chemical and mineralogical composition of the ore is known or can be obtained. For this reason it is advisable to make a semiquantitative emission spectrographic analysis and a coarse mineralogical examination of the sample. From this information one can usually determine whether an ore is neutral, reducing, or oxidizing. All this information is necessary to prepare an optimum charge so that maximum recovery of the noble metals may be realized.

If the ore is reducing, the "reducing power" of the ore should be established prior to fusing the sample. The term "reducing power," as used in fire assaying, is defined as the amount of lead that $1 \mathrm{~g}$ of the ore will produce when fused with an excess of litharge. For example, if we use $3.00 \mathrm{~g}$ of ore and obtain a lead button weighing $15.00 \mathrm{~g}$, the reducing power of the ore is

$$
\frac{15.00}{3.00}=5.00 \text {. }
$$

When the need arises to establish the reducing power of an ore, a preliminary fusion is employed using the following charge constituted 
in a 10-g fireclay crucible: $3 \mathrm{~g}$ ore, $10 \mathrm{~g} \mathrm{Na}_{2} \mathrm{CO}_{3}, 46 \mathrm{~g} \mathrm{PbO}, 3 \mathrm{~g} \mathrm{SiO}_{2}$, and $1 \mathrm{~g} \mathrm{Na}_{2} \mathrm{~B}_{4} \mathrm{O}_{7}$. Temperature and time of fusion are discussed in a later section.

Having established the reducing power of the ore, the following calculations are used to determine the amount of oxidant $\left(\mathrm{KNO}_{3}\right.$, commonly known as niter) required to obtain a desirable-sized button $(28-30 \mathrm{~g})$ when $15 \mathrm{~g}$ of sample is used:

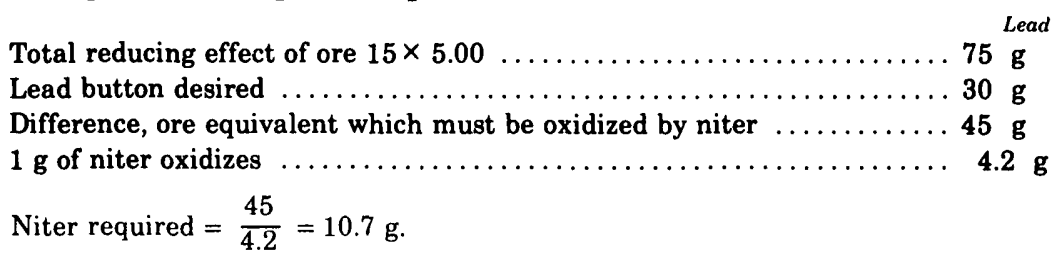

The approximate reducing power (R.P.) of some common minerals and reagents are as follows:

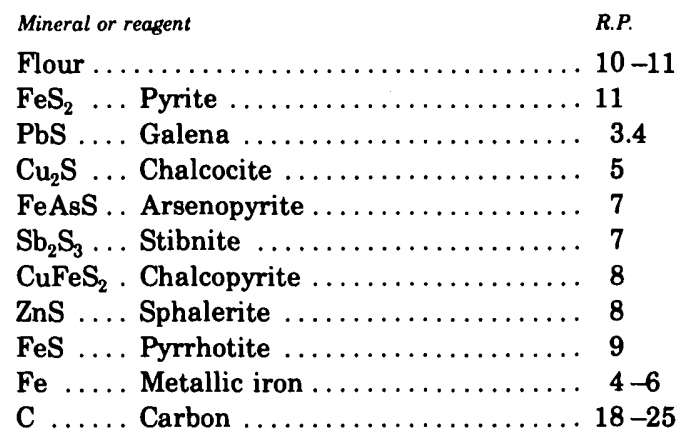

The oxidizing ores seldom need more than a slight increase in the amount of flour used. The following are some oxidizing ores and reagents and their oxidizing power (O.P.):

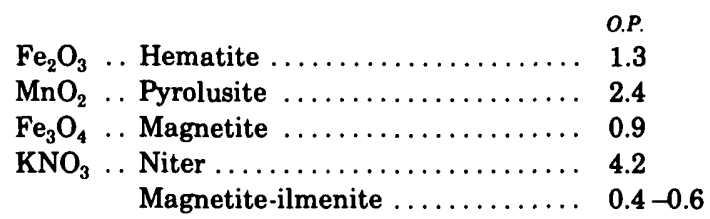

\section{ASSAY FLUX REAGENTS}

As noted in a previous section, the dry reagents, or flux components as they are commonly referred to, are added to the pulverized ore in a fireclay crucible to effect a fusion at an easily attained temperature. Each reagent serves a specific purpose in the fusion process, as follows: 
Sodium carbonate (soda). $-\mathrm{Na}_{2} \mathrm{CO}_{3}$ is a powerful basic flux and readily forms alkali sulfides in the crucible fusion. Some sulfates are formed in the presence of air, and for this reason $\mathrm{Na}_{2} \mathrm{CO}_{3}$ can be considered a desulfurizing and oxidizing agent. It melts at $852^{\circ} \mathrm{C}$; when heated to $950^{\circ} \mathrm{C}$ it undergoes a slight dissociation with the evolution of a small amount of $\mathrm{CO}_{2}$ and the liberation of about 0.4 percent of free alkali. Both the free alkali and sodium carbonate react to form silicates and aluminates.

Litharge. - $\mathrm{PbO}$ is also a basic flux and acts as an oxidizing and desulfurizing agent. It melts at $883^{\circ} \mathrm{C}$ and on being reduced it provides the lead necessary for the collection of the noble metals. Litharge has such a strong affinity for silica that, if the crucible charge does not contain enough silica, the $\mathrm{PbO}$ will attack the crucible walls and, if left long enough, will eat a hole through the crucible.

Silica. $-\mathrm{SiO}_{2}$ is a strong acidic reagent which combines with the metal oxides to form silicates, the foundation of almost all slags. It is added to the charge when the ore is deficient in silica to give a more fluid melt and to protect the crucibles from the corrosive action of litharge.

Borax glass. $-\mathrm{Na}_{2} \mathrm{~B}_{4} \mathrm{O}_{7}$ is extremely viscous when melted, but at a red heat it becomes fluid and a strong acid, dissolving and fluxing practically all the metallic oxides both acidic and basic. In addition, the fact that it fuses at a low temperature facilitates slagging of the ore and lowers the fusing point of all slags. For these reasons it is used in almost every crucible fusion.

Calcium fluoride. $-\mathrm{CaF}_{2}$ is used very frequently in our laboratory, especially when the aluminum content of the sample is 1 percent or more. It increases the fluidity of almost any charge.

Flour. - Flour is a reducing agent because of the carbon that it contains and is commonly used in the crucible charge.

Potassium nitrate. $-\mathrm{KNO}_{3}$, commonly known as niter, is a strong oxidizing agent. It melts at $339^{\circ} \mathrm{C}$, but at a higher temperature it decomposes giving off oxygen which oxidizes sulfur and many of the metals. In the Survey laboratory potassium nitrate is used chiefly to oxidize sulfide-bearing ores. It is advisable to establish the reducing power of the ore by using the calculations stated in a previous section because excessive amounts of nitre may cause boiling-over of the charge.

\section{SELECTION OF FLUX COMPONENTS}

The most important factor for a successful crucible fusion is the proper selection and amounts of the flux components (reagents). Because the selection of flux components is based primarily upon a knowledge of the chemical or mineralogical composition of the sample, 
it is advisable to perform an analysis of the sample prior to constituting the flux. A 6-step semiquantitative optical emission spectrographic analysis for 55 elements is the one most often used in our laboratory. By comparing the results for elements (of 1 percent or more) obtained from the semiquantitative analysis with the approximate chemical composition of the various types of samples listed in table 1, the proper charge can generally be constituted or calculated as described at the end of this section.

The approximate chemical compositions of the various ores and samples in table 1 were defined by examining the semiquantitative results on samples of the same type whose nominal description was supplied by geologists of the U.S. Geological Survey. In some cases only one to a few samples were available. Also, when the concentration of an element was determined by other methods it was included in the table, as for example in the galena and sphalerite composite where the concentration of $\mathrm{Pb}$ and $\mathrm{Zn}$ were 15.2 percent and 15.6 percent and listed as $G(15.2)$ and $G(15.6)$, respectively. All charges assigned to the various sample types were applied successfully in our laboratory. The quantities of the flux components have been held close to the minimum requirements of the ore or sample. This approach proved to be successful with consequent saving of time and reagents. Hopefully, this information will provide guidelines for others engaged in fire assaying.

A simple and rapid technique which is applied frequently to determine the minerals present when a spectrographic analysis of the sample is not available is that of vanning. Vanning, as applied in our laboratory, consists of taking about $0.5-1 \mathrm{~g}$ of the ground sample with a spatula and placing it on a $3.5-\mathrm{in} .(8.9-\mathrm{cm})$ watch glass. The sample is moistened with a few drops of tap water and stirred with the finger. Then two to three drops of $1: 1 \mathrm{HCl}$ are added. Any effervescence is generally due to evolution of $\mathrm{CO}_{2}$. When effervescence stops, more drops of $\mathrm{HCl}$ are added, and any resumption of effervescence is noted. Acid addition should be continued until effervescence ceases so that the amount of carbonate in the sample can be estimated. Sometimes the acid test is used in conjunction with a spectrographic analysis to establish the presence of carbonate. An odor of $\mathrm{H}_{2} \mathrm{~S}$ suggests sulfides and is particularly characteristic of sphalerite. Unfortunately, many sulfides, including pyrite, do not give an odor.

After the acid test is completed, a few drops of tap water are again added, stirred, and the suspended material is washed off. If a large amount of suspended material is present, a high clay content may be indicated. If the suspended material is black and finegrained and floats on top of the water as a film during the preliminary part of vanning, coal or organic matter should be suspected. Additional washings 
and stirrings may be necessary, care being taken to keep loss of coarser material to a minimum. The coarser material is spread out on the watch glass using a combined rotary and "flipping" motion after which this material is analyzed visually.

To interpret the results of vanning some generalities are presented.-

1. If the material has a high specific gravity (more than 4) and has a metallic brass-yellow to silvery appearance, sulfides, especially pyrite, should be suspected. Chalcopyrite, arsenopyrite, and galena also fall in this category.

2. Yellow material with low specific gravity is an indication of altered mica - one form of "fool's gold."

3. Red or reddish-brown materials with low specific gravity indicate iron-stained light-colored minerals, especially silicates.

4. Dark-red-brown or black minerals with high specific gravity indicate iron oxides (hematite, magnetite) or sulfides (sphalerite, coated pyrite, galena, and chalcocite). Magnetite may be detected by holding a horseshoe magnet below the watch glass and then moving it about.

5. Light-colored to white material with low specific gravity (after acid treatment) indicates quartz and most rock-forming silicates.

Other types of analyses such as X-ray fluorescence, chemical, and Xray diffraction, are occasionally employed.

Experience has shown that for basic and ultra basic rocks, including mineralized basic rocks, a flux high in borax should be used. This flux is also used for silicates where the $\mathrm{Fe}$ and $\mathrm{Mg}$ are each 5-10 percent or more. A convenient flux to use for these types of samples consists of 30 $\mathrm{g} \mathrm{Na}_{2} \mathrm{CO}_{3}, 35 \mathrm{~g} \mathrm{PbO}, 4 \mathrm{~g} \mathrm{SiO}_{2}, 35 \mathrm{~g} \mathrm{Na}_{2} \mathrm{~B}_{4} \mathrm{O}_{7}, 1 \mathrm{~g} \mathrm{CaF}_{2}$, and $3.2 \mathrm{~g}$ of flour for a 15-g sample. One component, $\mathrm{SiO}_{2}$, may be varied from 4 to $8 \mathrm{~g}$ depending upon the silica content of the sample.

$\mathrm{CaF}_{2}$ is another flux component which may vary widely $(0-15 \mathrm{~g}) \mathrm{de}$ pending upon the sample being fused. As mentioned previously, it increases the fluidity of most charges. A rule of thumb followed in our laboratory is that when the elemental aluminum concentration of the ore or sample is less than 1 percent, $\mathrm{CaF}_{2}$ is not added; if the aluminum concentration is $1-10$ percent, $1 \mathrm{~g}^{\text {of }} \mathrm{CaF}_{2}$ is added to the charge; if it is $10-20$ percent, $2 \mathrm{~g}$ is added. For high-grade aluminumbearing samples as much as $8 \mathrm{~g}$ may be used. Other samples not necessarily containing high aluminum but requiring an excessive amount ( $4 \mathrm{~g}$ or more) of $\mathrm{CaF}_{2}$ are black sands, magnetite, and calcium phosphate (bone ash). (See table 1.)

For chromite or chromitite samples a high borax charge in addition to an auxiliary flux is used. The main charge is made to contain $30 \mathrm{~g}$ $\mathrm{Na}_{2} \mathrm{CO}_{3}, 35 \mathrm{~g} \mathrm{PbO}, 10 \mathrm{~g} \mathrm{SiO}_{2}, 30 \mathrm{~g} \mathrm{Na}_{2} \mathrm{~B}_{4} \mathrm{O}_{7}, 1 \mathrm{~g} \mathrm{CaF}_{2}$, and $3.2 \mathrm{~g}$ flour plus $15 \mathrm{~g}$ of sample and the added noble metal ( $\mathrm{Ag}$ or $\mathrm{Au}$ ) which serves 
SELECTION OF FLUX COMPONENTS

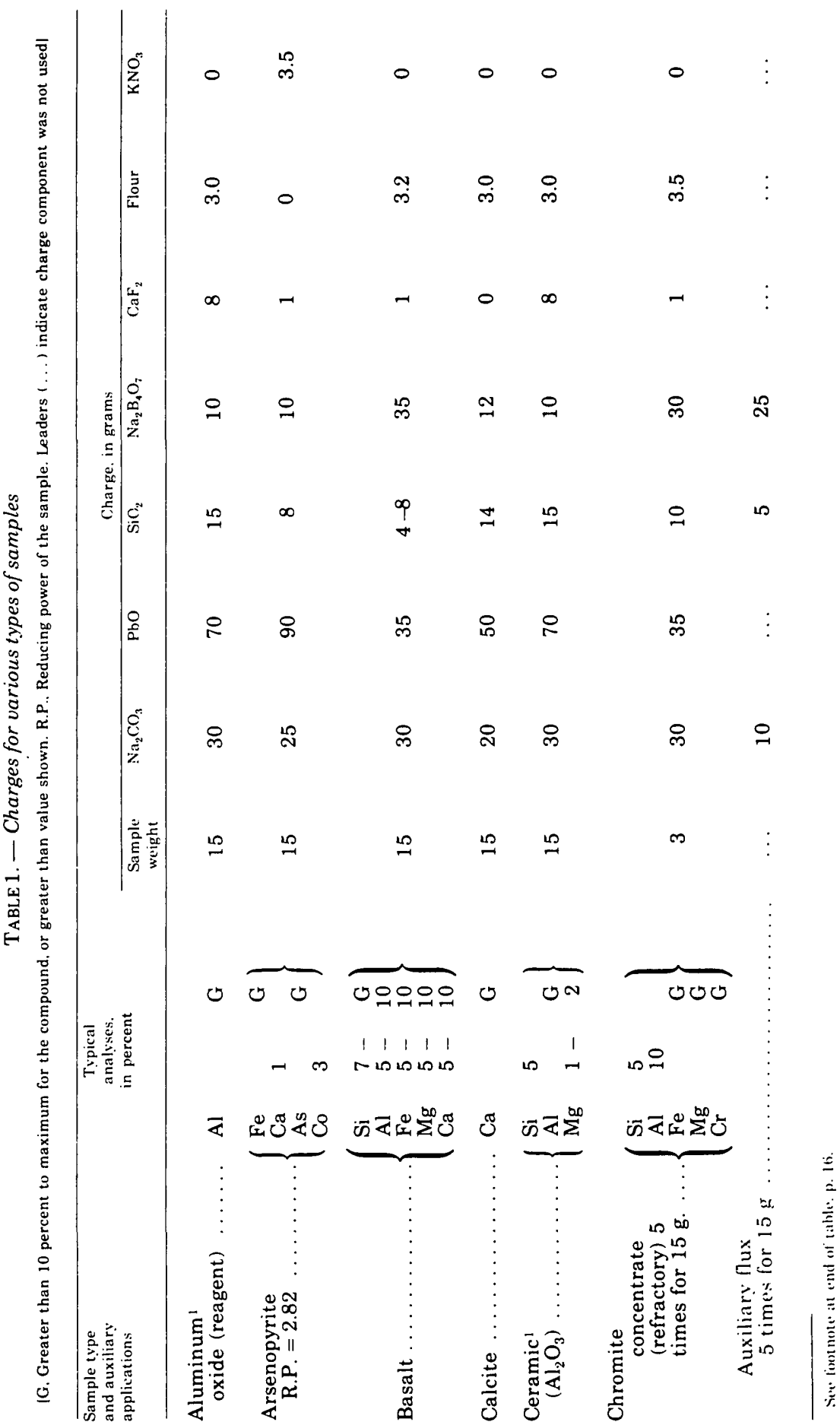




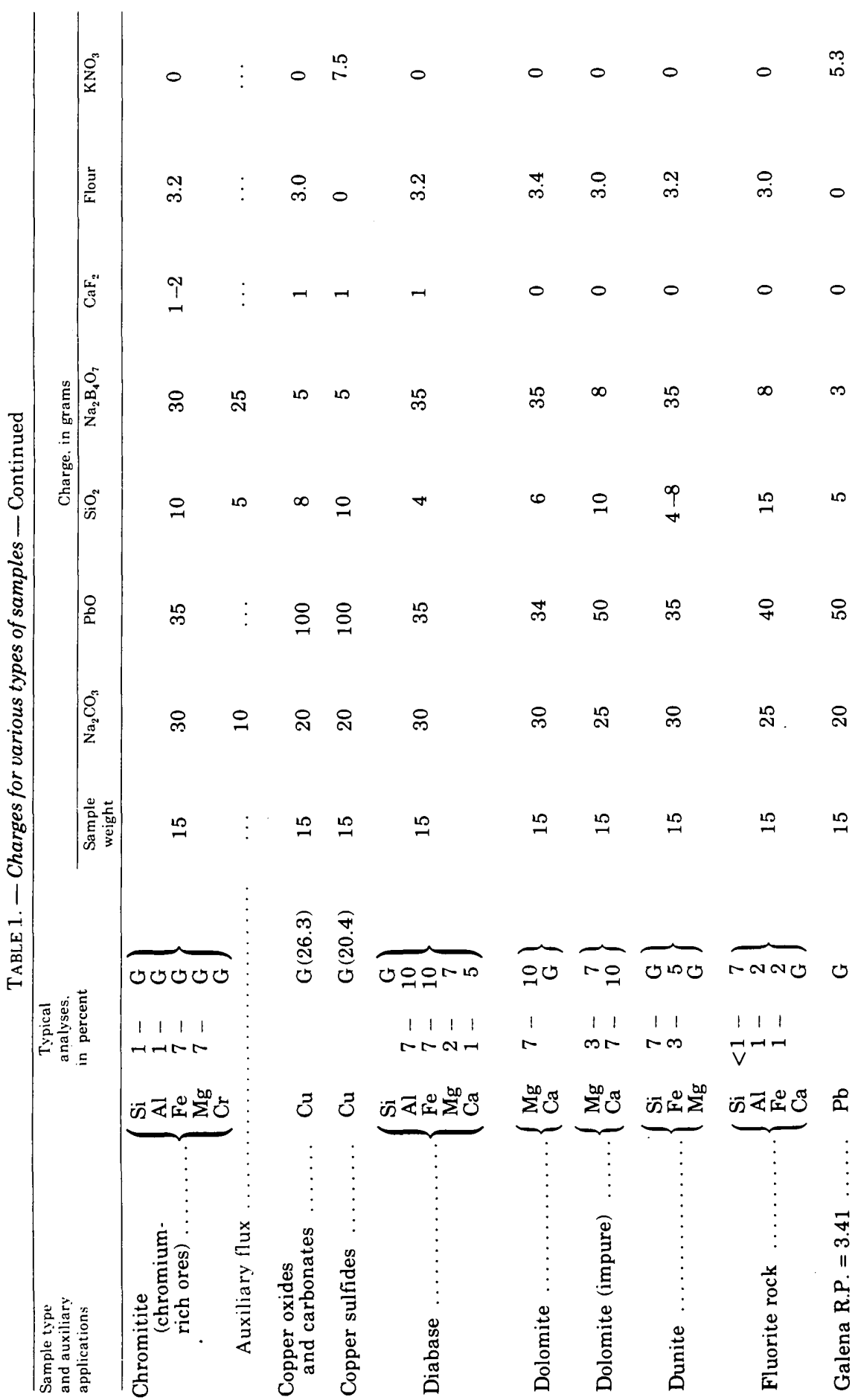




\begin{tabular}{|c|c|c|c|c|c|c|c|}
\hline$\stackrel{0}{\circ}$ & 0 & 0 & 0 & 0 & 0 & 0 & 0 \\
\hline 0 & $\stackrel{\rho}{\oplus}$ & $\stackrel{\infty}{\infty}$ & 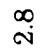 & 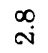 & $\stackrel{\circ}{\circ}$ & $\underset{\sim}{\sim}$ & ભુ \\
\hline- & - & $\neg$ & 0 & 10 & $\nabla$ & $\neg$ & $\uparrow$ \\
\hline L & 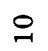 & $r$ & m & $\stackrel{1}{\circ}$ & $\infty$ & 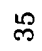 & pొ \\
\hline$\stackrel{m}{7}$ & n & $\begin{array}{c}00 \\
\stackrel{1}{+} \\
\stackrel{N}{7}\end{array}$ & - & $\stackrel{N}{\sim}$ & $\stackrel{10}{-10}$ & $\frac{N}{T}$ & $\stackrel{\infty}{\leftrightarrow}$ \\
\hline L & $\stackrel{20}{7}$ & 8 & in & in & in & 茆 & 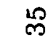 \\
\hline & $\stackrel{\leftrightarrow 2}{N}$ & $\stackrel{\leftrightarrow}{N}$ & ిิ & ฉి & $\stackrel{\mathscr{N}}{\mathrm{N}}$ & ஓ्లి & ిల్ల \\
\hline 10 & $\stackrel{20}{7}$ & $\stackrel{2}{\rightarrow}$ & 100 & $\stackrel{20}{\sim}$ & $\stackrel{7}{2}$ & $\stackrel{20}{2}$ & 20 \\
\hline
\end{tabular}

\section{สู่}

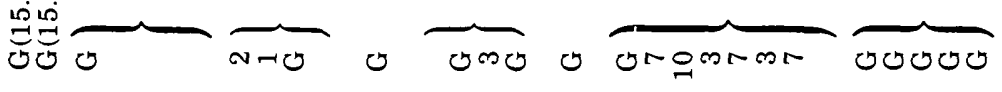

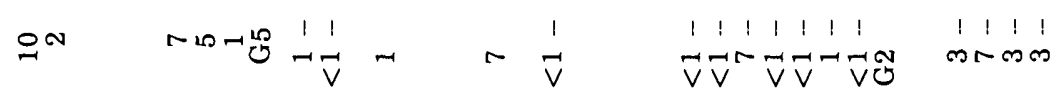

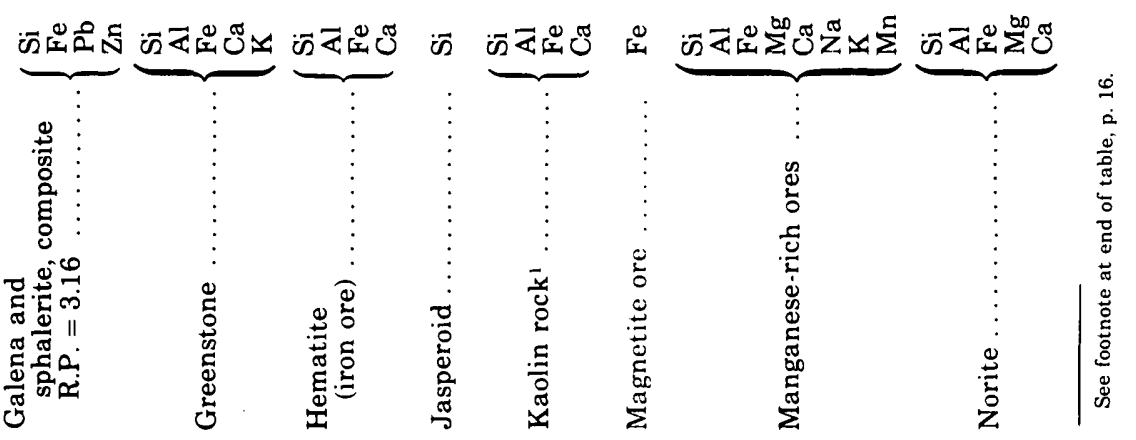




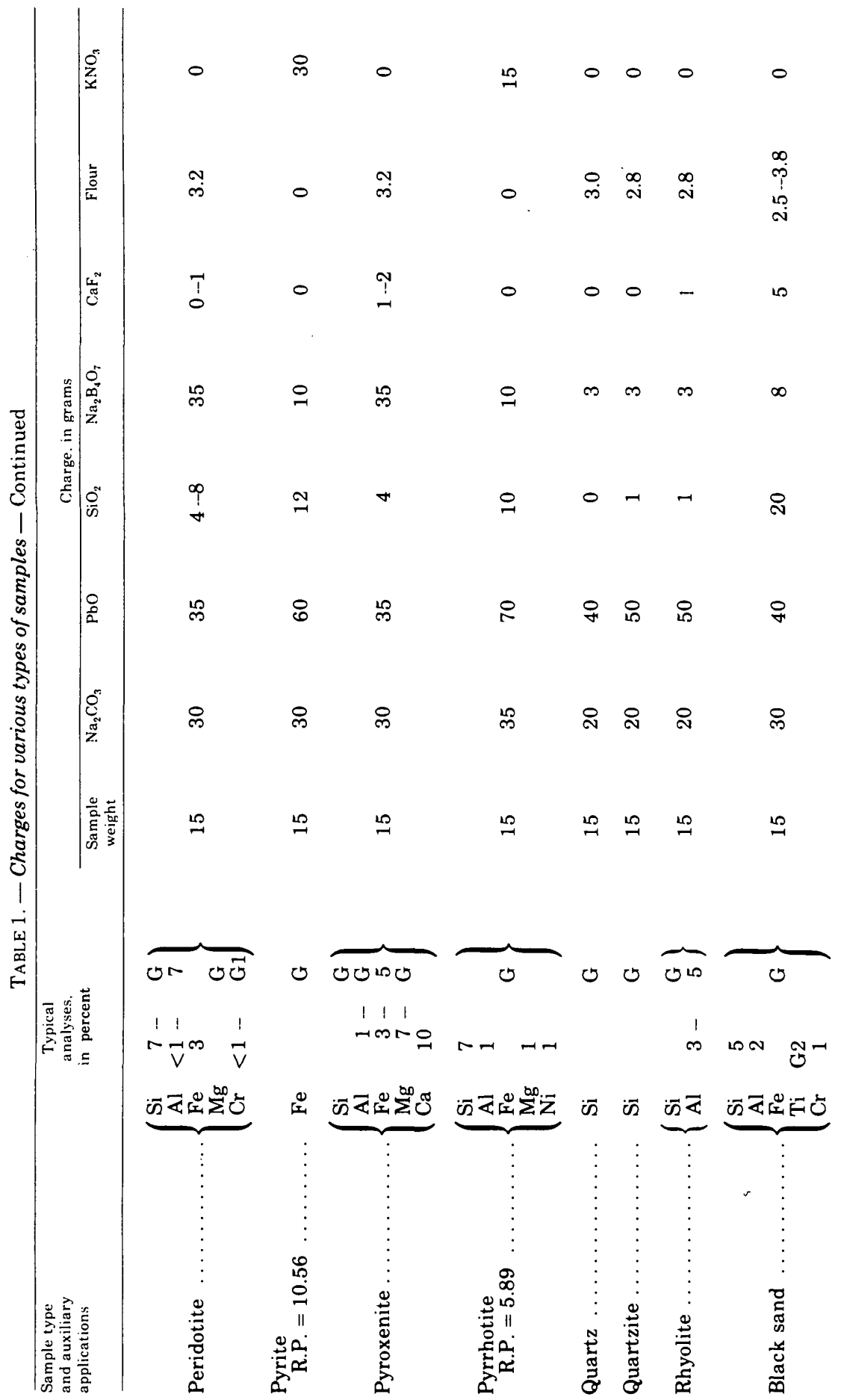




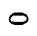

○

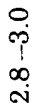

$N$

ల్ల

$\omega$

@

ฉ

$\stackrel{10}{10}$

19

ลิ

吕

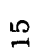

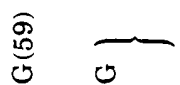

$\overbrace{000}$

음

11

N $\mathrm{L}$

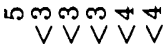

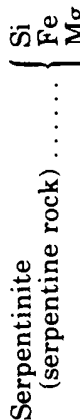

$\stackrel{n}{2}$

$\stackrel{2}{1}$

กొ

กิ

ल)

$\stackrel{0}{1}$

$\infty$

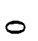

!

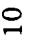

9

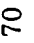

$\stackrel{8}{1}$

מ ח

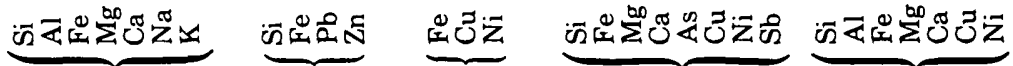
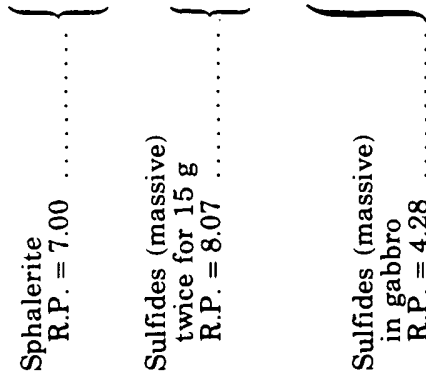

bo:

는

๖ำ

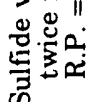




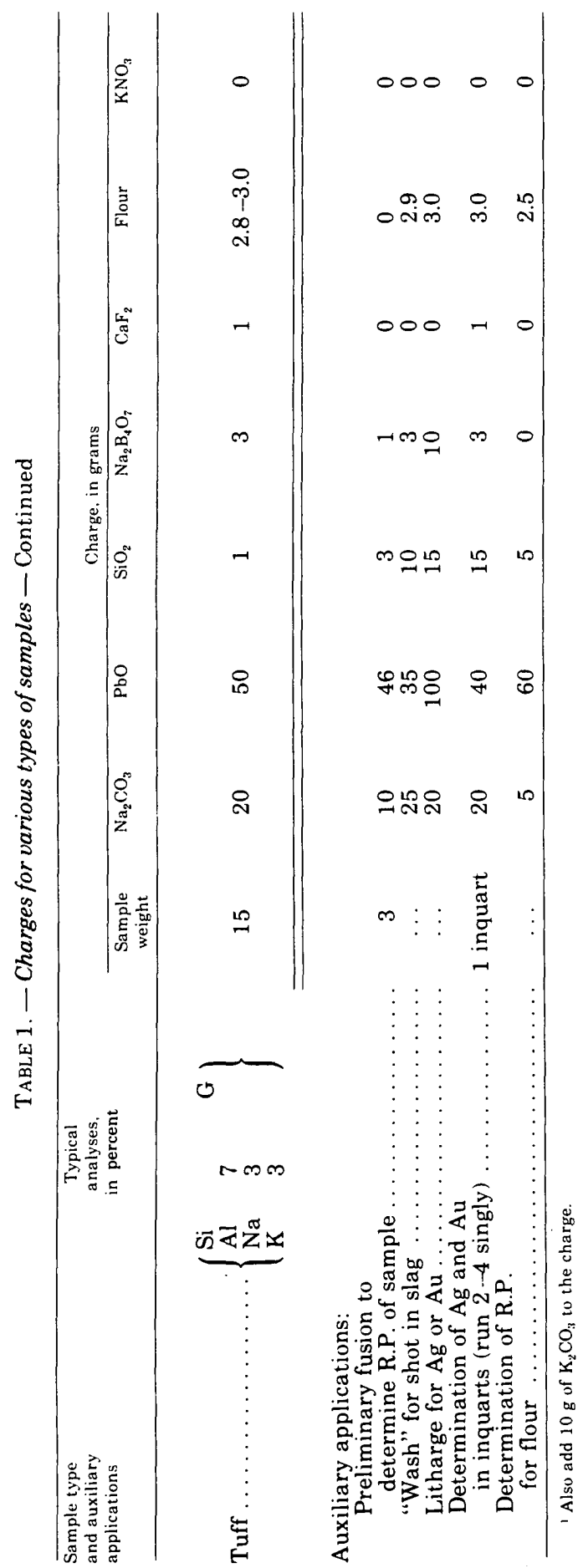


to collect the other noble metals during cupellation. These components are mixed well in a " 30 -g" fireclay crucible. The auxiliary flux consists of $10 \mathrm{~g} \mathrm{Na}_{2} \mathrm{CO}_{3}, 5 \mathrm{~g} \mathrm{SiO}_{2}$, and $25 \mathrm{~g} \mathrm{Na}_{2} \mathrm{~B}_{4} \mathrm{O}_{7}$, added to and mixed well in a "20-g" fireclay crucible. After fusion of the contents of both crucibles, the melt in the " 20 -g" crucible is added to the main charge. The procedure is described in detail in a following section.

Chromite concentrates or high-grade chromite ores are extremely difficult to fuse. Attempts to fuse $15 \mathrm{~g}$ in a single fusion using various combinations of flux components were not successful. For this reason five crucible fusions using $3 \mathrm{~g}$ of sample in each fusion are run. The flux used for each $3 \mathrm{~g}$ of sample consists of $30 \mathrm{~g} \mathrm{Na}_{2} \mathrm{CO}_{3}, 35 \mathrm{~g} \mathrm{PbO}, 10 \mathrm{~g}$ $\mathrm{SiO}_{2}, 30 \mathrm{~g} \mathrm{Na}_{2} \mathrm{~B}_{4} \mathrm{O}_{7}, 1 \mathrm{~g} \mathrm{CaF}_{2}$, and $3.5 \mathrm{~g}$ of flour mixed in a " 30 -g" fireclay crucible. To one of the five crucibles, $\mathrm{Ag}$ or $\mathrm{Au}$ is added to collect the other noble metals during cupellation. An auxiliary flux is also used consisting of $10 \mathrm{~g} \mathrm{Na} \mathrm{NO}_{3}, 5 \mathrm{~g} \mathrm{SiO}$, and $25 \mathrm{~g} \mathrm{Na}_{2} \mathrm{~B}_{4} \mathrm{O}_{7}$ mixed in a " 20 -g" crucible and treated in the same way as stated in the previous paragraph and detailed in a following section. The five lead buttons obtained, representing $15 \mathrm{~g}$ of sample, are combined and scorified to reduce the amount of lead so that a single convenient-sized ( $25-30 \mathrm{~g})$ lead button can be obtained for cupellation.

Samples high in iron-oxide content require observation during the fusion process, especially during the period when the temperature is raised from $900^{\circ}$ to $1000^{\circ} \mathrm{C}$. It is during this period that the contents of the crucible may boil over. To prevent this from happening, the crucibles are observed through a hole in the furnace door, and when the melt is seen to rise in the crucible the furnace door is opened and a small amount of water is poured on the melt by means of the furnace crucible (fig. 13). The door is then closed immediately, and the fusion is allowed to progress for the preset time. When an analysis of the sample shows that the oxides of iron are in high concentration, whereas the other major components are low (less than 3 percent), the following flux is successful: $25 \mathrm{~g} \mathrm{Na}_{2} \mathrm{CO}_{3}, 50 \mathrm{~g} \mathrm{PbO}, 15 \mathrm{~g} \mathrm{SiO}_{2}, 7-8 \mathrm{~g}$ $\mathrm{Na}_{2} \mathrm{~B}_{4} \mathrm{O}_{7}, 2 \mathrm{~g} \mathrm{CaF}_{2}$, and $3.8 \mathrm{~g}$ flour for a $15-\mathrm{g}$ sample. However, if the oxides or silicates of aluminum or titanium are high, as in black sands, the $\mathrm{CaF}_{2}$ is increased to $4-5 \mathrm{~g}$. If an ore contains appreciable amounts of silica, the quantity of reagent silica added may be correspondingly reduced so that the total silica present will equal the amount of sample taken; namely $15 \mathrm{~g}$ of silica for $15 \mathrm{~g}$ of sample.

If the description and an analysis of a sample or ore indicates the presence of sulfides, a preliminary fusion is recommended to establish the "reducing power" of the ore. The "reducing power" varies with different sulfides and a general flux cannot be designated. Here one relies on the elemental composition to indicate the sulfide present. 
The preliminary fusion is carried out at a temperature of $1050^{\circ} \mathrm{C}$ for 12-15 minutes and is described in detail in a following section.

When copper, nickel, or manganese are present in sulfides in appreciable amounts $(2-5$ percent), all components of the flux are increased. This is to increase the volume of the melt so that the constituents of the sample will dissolve more readily. For example, by an emission semiquantitative spectrographic analysis of a sample described as a sulfide-bearing fissure vein, the percentages of the following elements were determined: $\mathrm{Fe}>10 ; \mathrm{Zn}>10 ; \mathrm{Mn}>2 ; \mathrm{Pb}$, 3 ; $\mathrm{Cu}, 1 ; \mathrm{Si}, 2$; and $\mathrm{Al}, 0.2$. By a preliminary fusion the "reducing power" of this sample was determined to be 5.37. The first flux, used for a sphalerite, was made to contain $20 \mathrm{~g} \mathrm{Na}_{2} \mathrm{CO}_{3}, 60 \mathrm{~g} \mathrm{PbO}, 8 \mathrm{~g} \mathrm{SiO}_{2}$, $6 \mathrm{~g} \mathrm{Na}_{2} \mathrm{~B}_{4} \mathrm{O}_{7}$, and $12 \mathrm{~g} \mathrm{KNO}_{3}$ for a 15 -g sample. After fusion, this flux produced an undesirable stony slag. A repeat fusion, where all components of the flux were increased with the exception of $\mathrm{KNO}_{3}$, contained $30 \mathrm{~g} \mathrm{Na}_{2} \mathrm{CO}_{3}, 90 \mathrm{~g} \mathrm{PbO}, 12 \mathrm{~g} \mathrm{SiO}_{2}, 10 \mathrm{~g} \mathrm{Na}_{2} \mathrm{~B}_{4} \mathrm{O}_{7}$, and $11 \mathrm{~g} \mathrm{KNO}_{3}$. This flux produced an acceptable slag and lead button. The preceding example shows that a flux used for a mineral such as sphalerite $(\mathrm{ZnS})$ would not necessarily produce an acceptable fusion when other elements or compounds are present in sufficient amounts.

Siliceous samples or ores containing 60 percent silica or more and low in the ferromagnesian silicates usually give good fusions using the following flux: $20 \mathrm{~g} \mathrm{Na}_{2} \mathrm{CO}_{3}, 50 \mathrm{~g} \mathrm{PbO}, 0-3 \mathrm{~g} \mathrm{SiO}_{2}, 3-5 \mathrm{~g} \mathrm{Na}_{2} \mathrm{~B}_{4} \mathrm{O}_{7}, 1 \mathrm{~g}$ $\mathrm{CaF}_{2}$, and $2.8 \mathrm{~g}$ flour for $15 \mathrm{~g}$ of sample.

Samples high in aluminum content are difficult to fuse and for this reason $\mathrm{K}_{2} \mathrm{CO}_{3}$, in addition to the other flux components, is added to the charge. The mixture of $\mathrm{K}_{2} \mathrm{CO}_{3}$ and $\mathrm{Na}_{2} \mathrm{CO}_{3}$, lowers the fusion temperature more than would either compound alone and, therefore, allows more time for reaction to take place.

From the data given in table 1, one can also adjust the charge if a mixture of minerals is contained in one sample. For example, the following are charges for calcite and quartz, and an adjusted charge if the sample were to contain half calcite and half quartz; all quantities are in grams:

\begin{tabular}{lccc}
\hline & Calcite & Quartz & $\begin{array}{c}\text { Half calcite, } \\
\text { half quartz }\end{array}$ \\
\hline Ore $\ldots \ldots \ldots \ldots \ldots \ldots \ldots$ & 15 & 15 & 15 \\
$\mathrm{Na}_{2} \mathrm{CO}_{3} \ldots \ldots \ldots \ldots \ldots \ldots$ & 20 & 20 & 20 \\
$\mathrm{PbO} \ldots \ldots \ldots \ldots \ldots \ldots \ldots$ & 50 & 40 & 45 \\
$\mathrm{SiO}_{2} \ldots \ldots \ldots \ldots \ldots \ldots \ldots$ & 14 & 0 & 7 \\
$\mathrm{Na}_{2} \mathrm{~B}_{4} \mathrm{O}_{7} \ldots \ldots \ldots \ldots \ldots \ldots$ & 12 & 3 & 18 \\
$\mathrm{CaF}_{2} \ldots \ldots \ldots \ldots \ldots \ldots \ldots$ & 0 & 0 & 0 \\
Flour $\ldots \ldots \ldots \ldots \ldots \ldots$ & 3.0 & 3.0 & 3.0 \\
\hline
\end{tabular}

1 Rounded off to 8 .

The adjusted charge is obtained by calculating the difference in 
amount of each flux component and dividing by two. The result is then added to the smaller figure.

\section{SAMPLE PREPARATION}

In preparing the sample for analysis one must constantly be on guard to prevent contamination of the sample. A significant change in pulverizing machinery consisting of replacing steel grinding plates with high-alumina ceramic plates has reduced contamination to where it is almost negligible (Barnett and others, 1955; Myers and Havens, 1970; Moreland and Myers, 1973). (See fig. 1 for grinding room arrangement.)

Samples submitted to the U.S. Geological Survey vary in form as well as composition. However, the basic procedure for pulverizing most samples is essentially the same. If the samples are received in huge chunks, they are reduced to pieces of $2-3$ in. $(5-7.6 \mathrm{~cm})$ with a sledge hammer and steel plate. They are then passed through a large jaw crusher which reduces the size to about 0.75 in. $(1.9 \mathrm{~cm})$. Following this, the samples are passed through a small jaw crusher (fig. 2) which reduces them to pea size $(0.25$ in., about $0.5 \mathrm{~cm})$ or smaller.

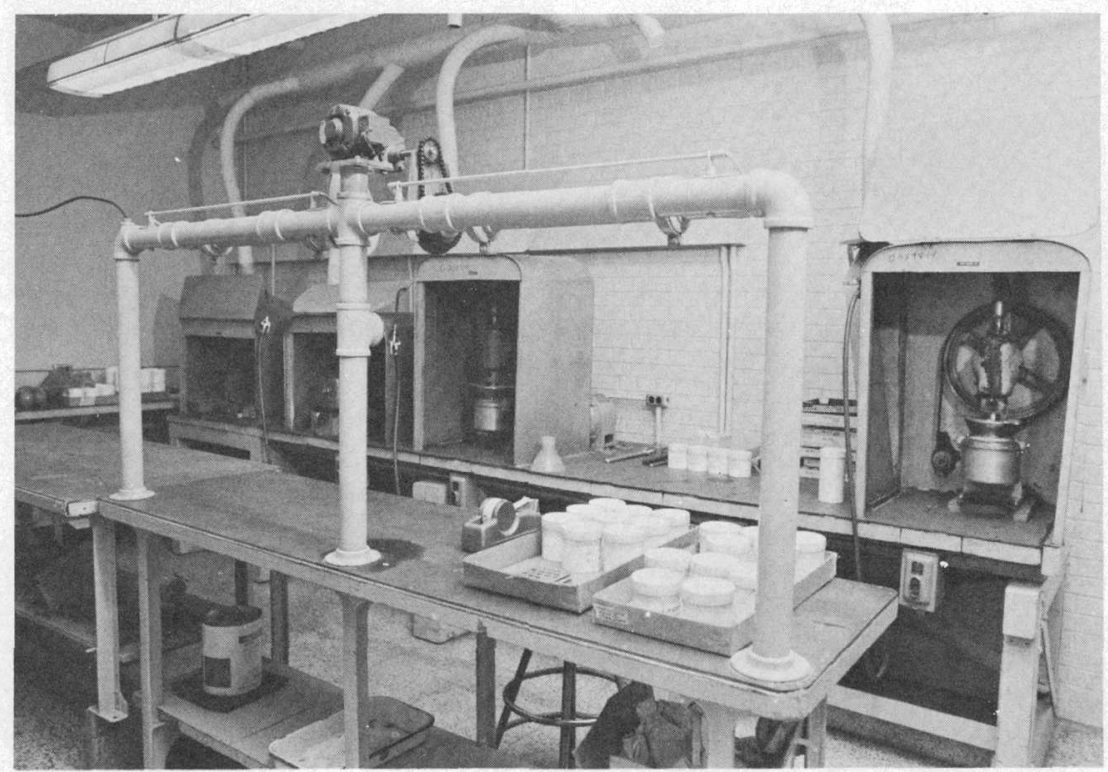

FIGURE 1. - Grinding-room arrangement. Each unit has its own hood to which an exhaust duct is connected to remove dust. Each unit is equipped with a hinged lid which is dropped to protect the operator when unit is in use. Motor-driven rotating hollow tubes are used to mix samples and are attached on the opposite side of the pipe superstructure shown in center foreground. 

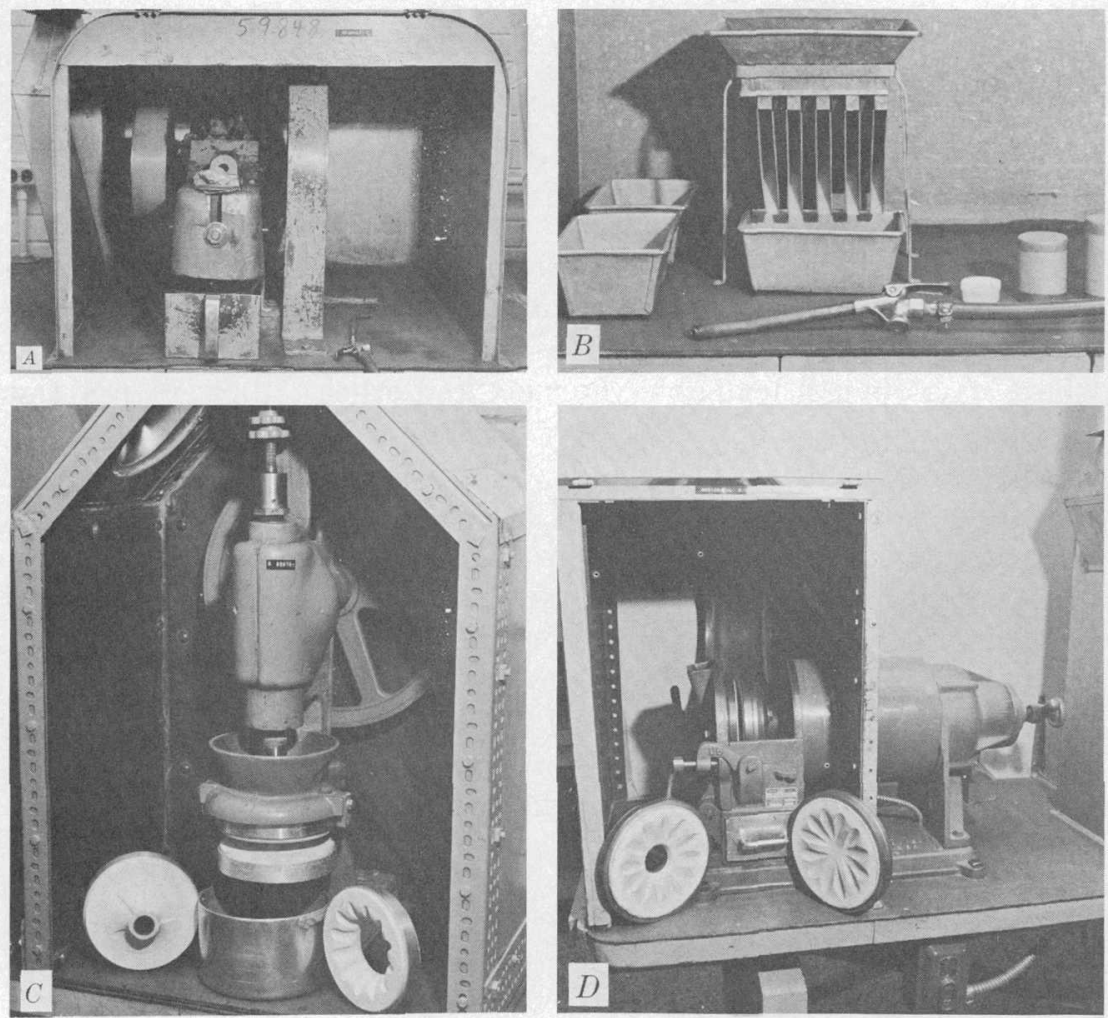

FIGURE 2.- Some of the grinding-room equipment used in preparing a sample for analysis. $A$, Small jaw crusher used to reduce the samples to pea size $(0.25$ in., about $0.5 \mathrm{~cm}$ ) or smaller; $B$, Jones splitter shown with one of several compressed-air nozzles used for cleaning equipment after each sample; $C$, Six-inch vertical Bico ceramic pulverizer with set of ceramic plates attached and second set of plates in foreground; $D$, Eight-inch horizontal Bico ceramic pulverizer with ceramic plates in foreground.

When the amount of crushed sample is large, it is next passed over a Jones splitter one or more times to obtain enough representative sample to fill a 4-oz (about 120-ml) and a 0.5-pint (about 240-ml) capacity container. The $4-\mathrm{oz}(120-\mathrm{ml})$ portion is passed through a 6 -in. vertical $\mathrm{Bico}^{2}$ ceramic pulverizer (fig. 2) which grinds the sample to -80 mesh. A hard rock sample may require two passes through the pulverizer to attain the necessary fineness. The pulverized sample is collected in an aluminum "ore pan" from which it is transferred to the same 4-oz $(120-\mathrm{ml})$ container in which a mixer card was inserted. The container

\footnotetext{
${ }^{2}$ Brand names and company names are included in this manual for the benefit of the reader and do not constitute endorsement of the product or company by the U.S. Geological Survey.
} 
is capped and placed in a roller mixer for about 20-30 minutes to mix the sample well. This is the sample used for analysis. The 0.5-pint, pea-sized portion is retained for storage in the event there is a need for more sample.

Should it be necessary to prepare a large-size sample for multiple uses, such as separation of zircon for age determination, the sample may need to be ground using an 8-in. horizontal Bico ceramic pulverizer. This grinds at a considerably faster rate than the 6 -in. pulverizer. Samples smaller than $1 \mathrm{oz}(29.6 \mathrm{ml})$ in volume should not be ground in the 6 -in. vertical pulverizer. Such samples are ground by hand using a Plattner (diamond) mortar followed by grinding with a large agate mortar and pestle.

A few types of samples are not pulverized with ceramic plates. Examples of these are oil shales containing a high percentage of oil or asphaltic materials and rock samples containing appreciable amounts of garnet or corundum. The oil shales tend to "gum up" the plates causing severe chattering of the machine, so a "hammer mill" (fig. 3) is used instead. Rocks containing garnet pose a danger, due to their hardness, of grooving the ceramic plates especially if the garnets have sharp edges. Such samples are pulverized by hand using a Plattner mortar followed by grinding in an agate mortar.

\section{EQUIPMENT AND MATERIALS}

The equipment, crucibles, cupels, and scorifiers are shown in figures 1 to 20 . The depressions in the mold (fig. 4) are initially coated with a
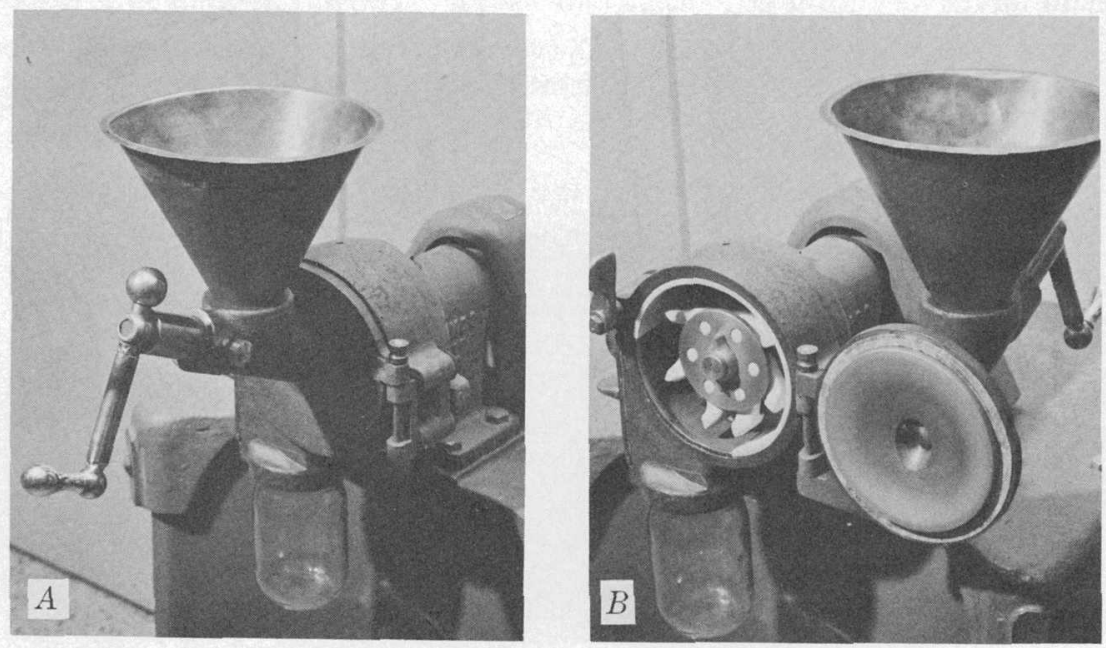

FIGURE 3. - $A$, Hammer mill used for pulverizing oil shales and asphaltic materials; $B$, Mill shown open to display the ceramic hammers that pulverize the material. 
slurry consisting of $\mathrm{Fe}_{2} \mathrm{O}_{3}$ and distilled water and applied with a paintbrush. The coating is allowed to dry completely before use after which the depressions are lightly wiped with a cloth to remove any excess $\mathrm{Fe}_{2} \mathrm{O}_{3}$. The coating aids in preventing the melt from sticking to the mold. The mold is coated infrequently thereafter and only when the need arises, which is indicated when part of the solidified melt sticks to the mold.

The "Pueblo Brand" litharge, C. P. and the "Pueblo Brand" test lead, C. P., both produced by American Smelting and Refining Company (ASARCO), can be purchased in 100 - and 50-1b (about 45.5- and $22.7-\mathrm{kg}$ ) containers from Van Waters and Rogers or MSI Industries, Inc., Denver, Colo. This brand of litharge and test lead are especially recommended because we find them to be "silver-free."

Sodium carbonate, produced by Mallinckrodt (in 1976, catalog number 7527) in the anhydrous granular form and of analytical reagent grade, and sodium borate, $\mathrm{Na}_{2} \mathrm{~B}_{4} \mathrm{O}_{7}$, produced by Matheson Coleman \& Bell (MC/B) (in 1976, catalog number SX376) in the anhydrous granular form, can be purchased from Sargent-Welch in $25-\mathrm{lb}(11.3-\mathrm{kg})$ containers. Silica, produced by the Ottawa Silica Co., Ottawa, Ill., is obtained as silica sand, natural grain. The fireclay crucibles are purchased in " 30 -g," "20-g," and " 10 -g" capacities, and the cupels, made of pure bone ash, have diameters of $1.5 \mathrm{in} .(3.8 \mathrm{~cm})$ and $1.75 \mathrm{in}$. $(4.4 \mathrm{~cm})$. The crucibles and cupels are obtained from DFC Ceramics, Canon City, Colo. The size designations for the fireclay crucibles indicate the amount of ore that can be assayed in the crucible; it will hold that amount of ore plus the necessary flux. However, although we commonly use $15 \mathrm{~g}$ of sample, the " 30 -g" crucible is generally used. The fireclay scorifiers, commonly referred to as scorifying dishes, are also purchased from DFC Ceramics. The dishes having outside

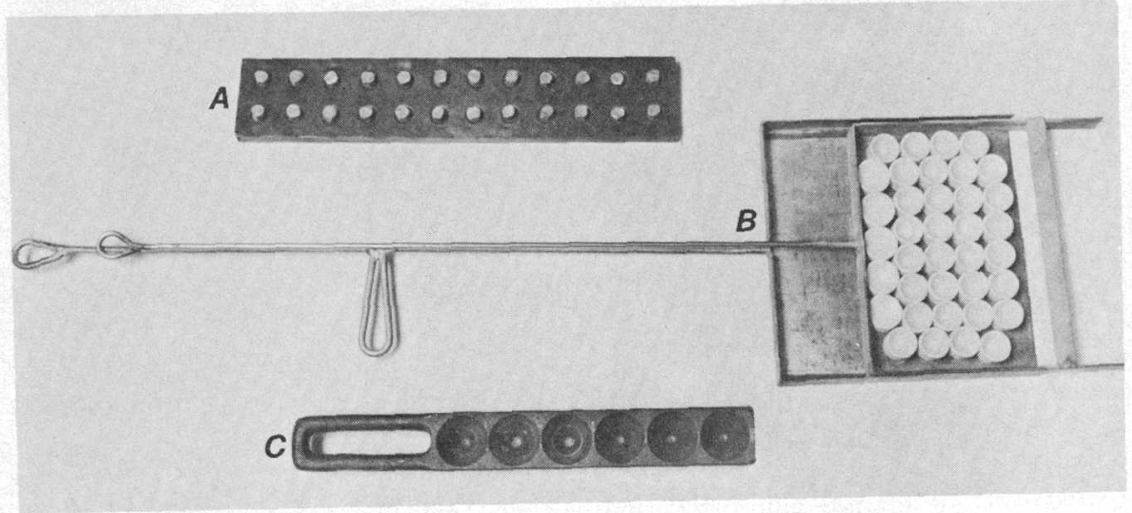

FIGURE 4.- Some furnace-room equipment. $A$, Button tray with lead buttons; $B$, Cupel charging tray with cupels; $C$, Pouring mold to receive molten charge. 
diameters of 2.5 in. $(6.4 \mathrm{~cm})$ and 3 in. $(7.6 \mathrm{~cm})$ are designated "DFC Bartlett," and those with outside diameters of $3.5 \mathrm{in}$. are designated "DFC Regular" (fig. 5).

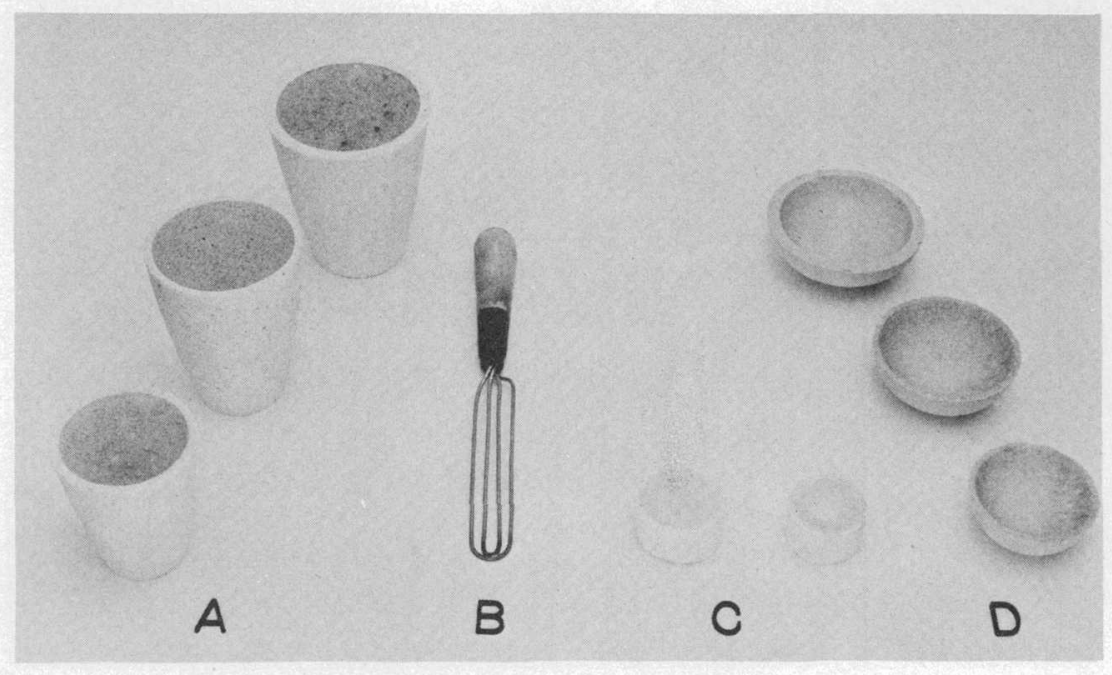

Figure 5. - Furnace-room supplies. $A$, Three sizes of fireclay crucibles; $B$, Wire-type mixer; $C$, Two sizes of bone-ash cupels; $D$, Three sizes of low-form fireclay scorifiers.

\section{WEIGHING THE COMPONENTS}

Before weighing the components for the crucible charge, the fireclay crucibles are cleaned with a brush and marked for identification with a Hi-Temp marker using the sample number. All components for the crucible fusion are weighed on a Mettler single-pan balance having a capacity of $120 \mathrm{~g}$ (Model p 120, fig. 6). Each component is weighed in sequence for all samples. For example, the $\mathrm{Na}_{2} \mathrm{CO}_{3}$ for all samples is weighed and transferred to each crucible, followed by the $\mathrm{PbO}$ for each sample. Up to 12 samples can be prepared and fused at one time.

After all the flux components have been weighed and transferred to the crucibles, the lead envelope containing the gold wire, or the silver inquart, or the silver wire is added. Then the entire ground sample is spread out on a piece of paper and "leveled off" with a long spatula to a thickness of about $1 \mathrm{~cm}$. To ensure a representative sample, small portions are taken with a spatula from various points along the edges and middle and transferred to the weighing pan until $15 \mathrm{~g}$ are obtained. The 15-g sample is transferred to the crucible, and the contents are mixed thoroughly with a wire-type mixer (fig. 5) until a uniformly colored mixture is obtained. 


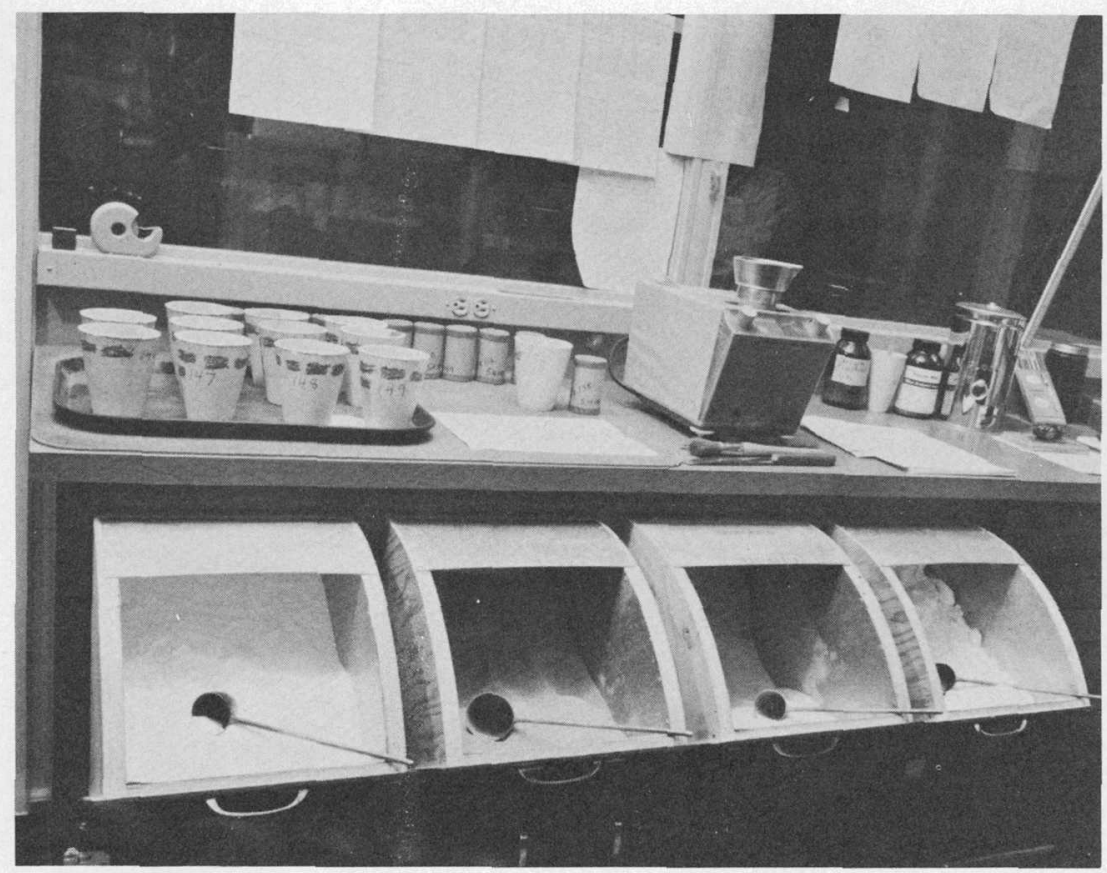

FIGURE 6. - Reagent-room arrangement showing bins (from left to right) in which $\mathrm{Na}_{2} \mathrm{CO}_{3}, \mathrm{PbO}, \mathrm{SiO}_{2}$, and $\mathrm{Na}_{2} \mathrm{~B}_{4} \mathrm{O}_{7}$ are stored. Other reagents are shown on bench top with single-pan Mettler balance used to weigh reagents and samples. Completed sample-charge forms are shown hanging above bench.

\section{SELECTION OF SAMPLE WEIGHT}

As mentioned previously, $15 \mathrm{~g}$ of sample is usually used in fire assaying at the Denver laboratory of the U.S. Geological Survey. The concentration of each noble metal in the sample is reported in parts per million. In countries where the metric system is used, values are reported in grams per metric ton, which is the equivalent of parts per million. The latter can be easily converted (using appropriate conversion factor) to various units for expressing concentration whether it be North American, English, or other systems.

At other laboratories in North America, it is customary to use a factor weight of sample such that each milligram of a noble metal in the sample is equivalent to one troy ounce in one avoirdupois ton $(2000 \mathrm{lb})$ of ore. As one ton contains 29167 troy ounces, the assay ton containing $29.167 \mathrm{~g}$ is the factor weight normally used. Milligrams per assay ton can then be reported as troy ounces per short ton of ore. In England and Australia the long ton of $2240 \mathrm{lb}$ is used, and the factor weight becomes $32.667 \mathrm{~g}$. These factor weights are termed assay tons. 


\section{THE CRUCIBLE FUSION}

\section{THEORY OF THE CRUCIBLE FUSION}

Most ores are by themselves infusible, but if pulverized and mixed in proper proportion with suitable dry reagents (flux components) in a fireclay crucible the mixture will fuse at an easily attained temperature. It is assumed that the ore and flux components are so intimately mixed that each particle of ore is in contact with particles of the flux components. As the temperature of the mass is gradually raised, part of the $\mathrm{PbO}$ (litharge) is reduced to lead (commencing at $500^{\circ}-550^{\circ} \mathrm{C}$ ) by the carbon (in the flour) or the sulfides of the charge. The mist of lead droplets produced collects or alloys with the noble metals released from the surrounding particles of decomposed ore. Part of the $\mathrm{PbO}$ forms slag-miscible compounds, such as the lead silicates, which are absorbed by the slag.

The conditions should be such that the slag remains viscous until the ore particles are thoroughly decomposed and every particle of the noble metals has been taken up by the adjacent suspended droplets of lead. After this point has been reached, the temperature is raised (dis-

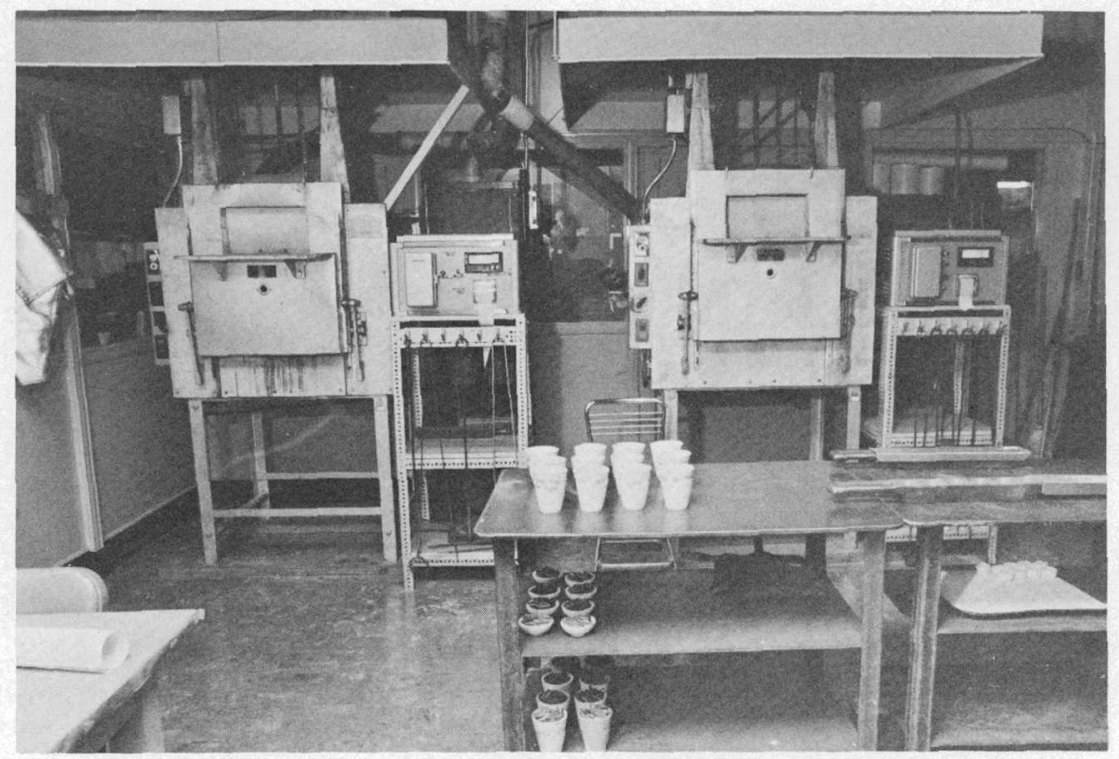

FIGURE 7. - Furnace-room arrangement. Pyrometrically controlled electric assay furnaces capable of attaining $1200^{\circ} \mathrm{C}$ are shown in background with exhaust hoods (canopy-type) above each. Furnace tools are shown hanging to the right of each furnace, and two steel tables on which hot materials may be placed are shown in foreground. 
cussed later) to ensure that the slag is thoroughly fluid. This condition allows the lead droplets to accrete and fall like fine raindrops through the slag to form the lead button in which the noble metals are concentrated.

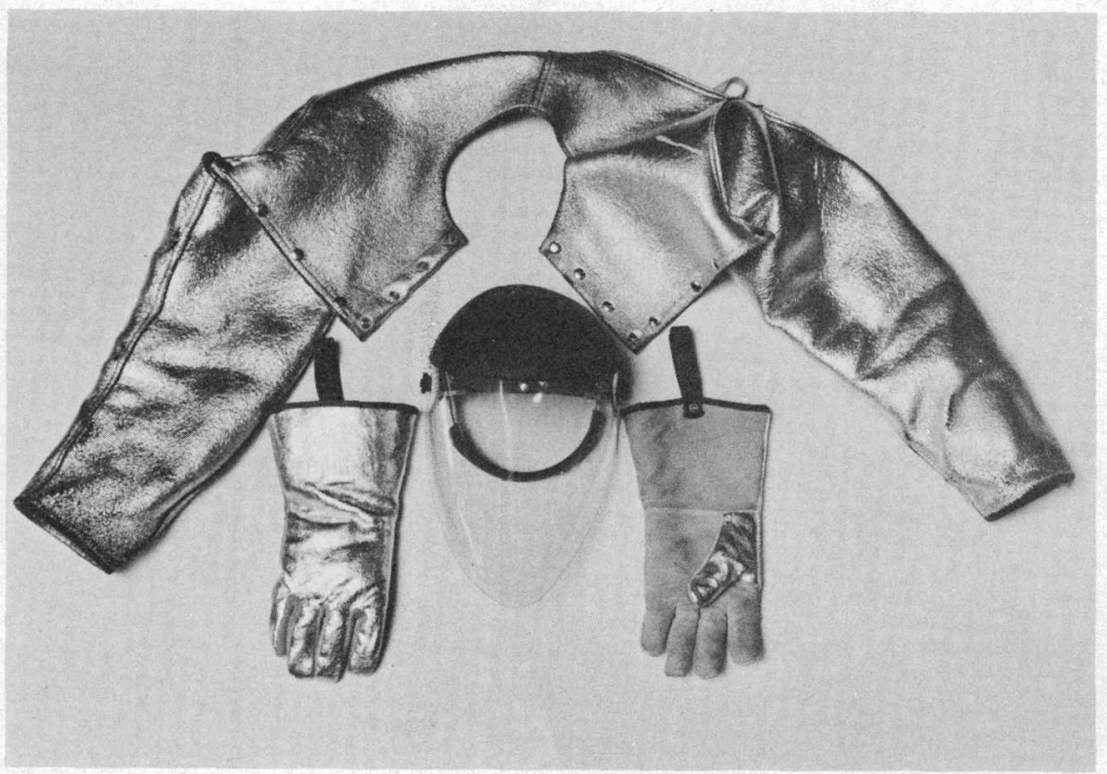

FIGURE 8. - Heat protective equipment worn for most fire-assay operations.

\section{FUSION}

The furnace is brought to a temperature of $1000^{\circ} \mathrm{C}$, after which the heat protective equipment shown in figure 8 is worn. The crucibles with their contents are now placed in the furnace in rows of four using a charging fork (figs. 9, 10) and starting at the rear of the furnace. A space of about $0.25 \mathrm{in} .(0.5 \mathrm{~cm})$ between crucibles is maintained in the event of boilover. The last two rows (at the front of the furnace) are shielding crucibles (crucibles filled with graphite electrodes), also referred to as "deadheads" and "dummies" (fig. 11). The shielding crucibles aid in providing a somewhat neutral atmosphere in an otherwise oxidizing one. Also, they provide protection against drafts which are prevalent around the furnace door.

After the furnace door is closed, the temperature is turned down to $900^{\circ} \mathrm{C}$ and the timer is set for 17 minutes for $1-10$ samples $(20$ minutes when fusing 11 or 12 samples). In the meantime, the iron molds in which the fusions are to be poured are placed on the steel ta- 


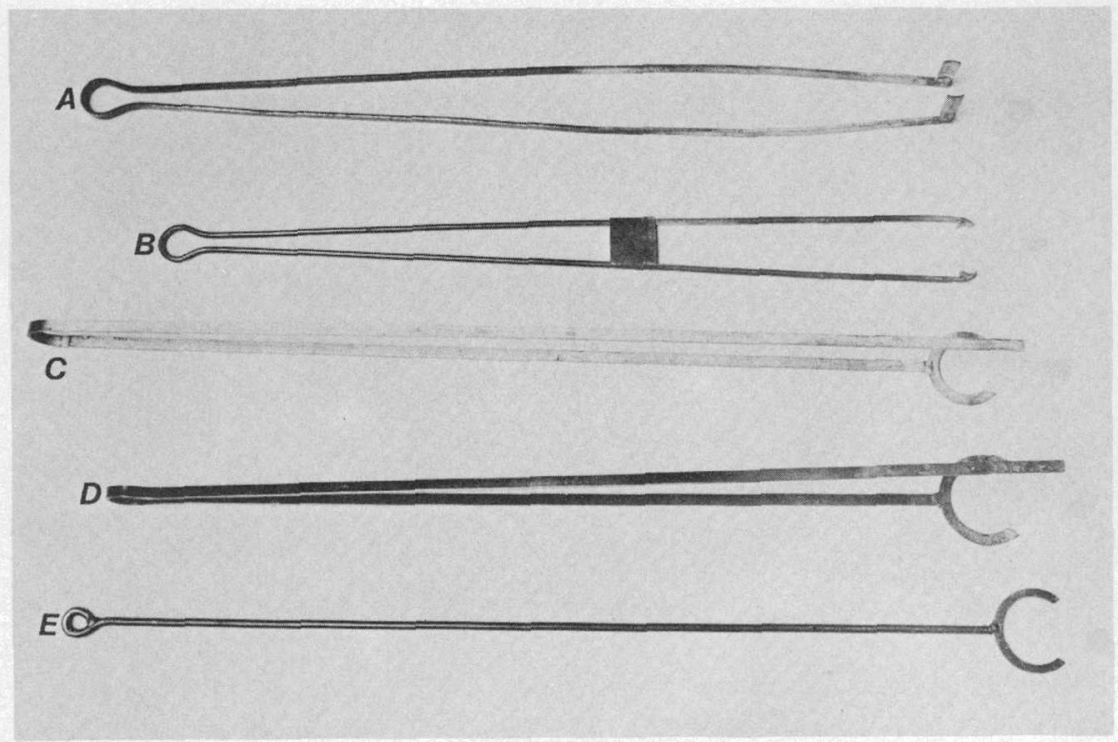

Figure 9. - Furnace tools. $A$, Cupel tongs; $B$, Button tongs; $C$ and $D$, Two sizes of crucible-scorifier tongs; $E$, Charging fork.

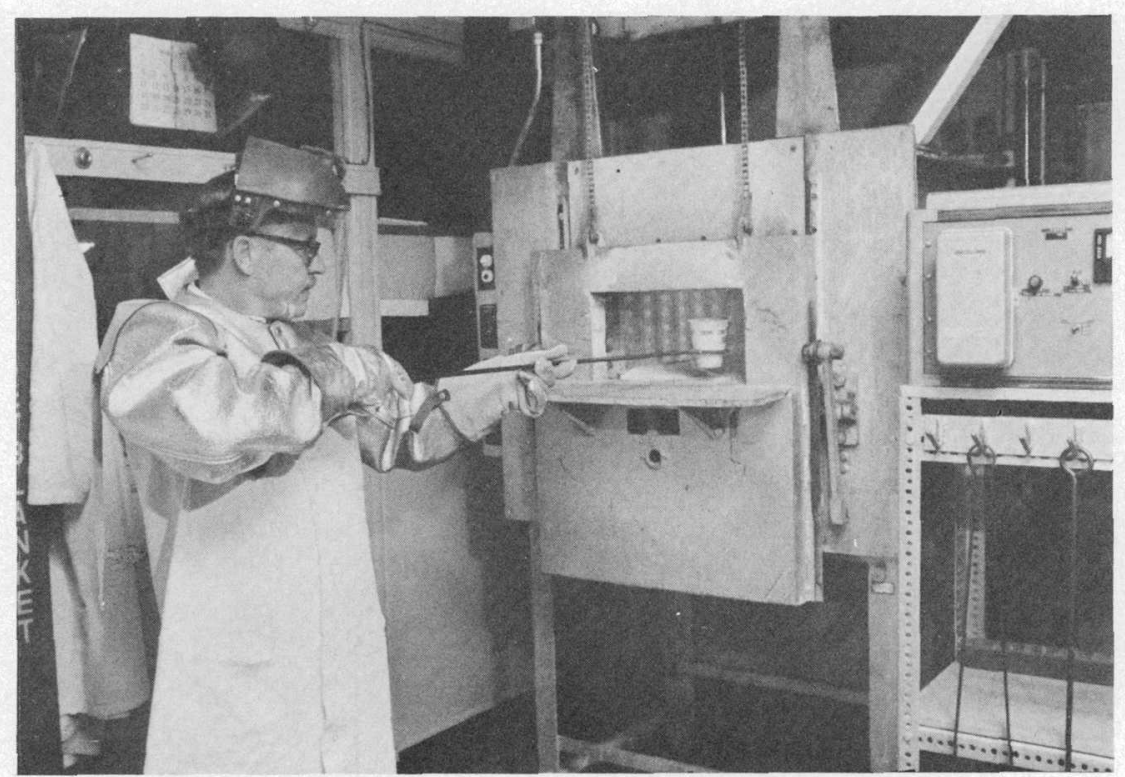

FIGURE 10. - Placing the fireclay crucibles with contents in furnace, using a charging fork. Note that heat protective equipment is worn. 


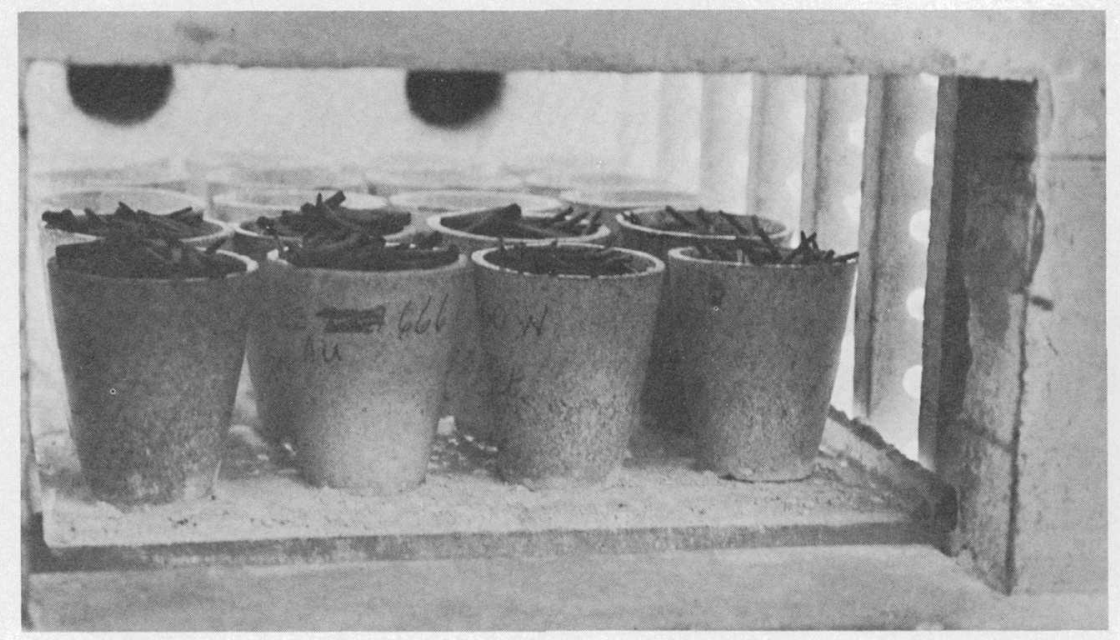

FiguRE 11. - Fireclay crucibles with contents shown in furnace, with two rows of shielding crucibles in foreground.

ble with their aluminum covers. After 17 minutes the temperature is raised to $1000^{\circ} \mathrm{C}$ and the timer is set for an additional 15 minutes $(20$ minutes when fusing 11 or 12 samples). At the end of this time, the furnace door is opened, and the shielding crucibles are removed with the charging fork. Then the fusion crucibles are removed singly using the crucible-scorifier tongs (fig. 9). After each removal, the door of the furnace is closed by tripping the switch with one hand, being careful to clench the fusion crucible firmly with the crucible-scorifier tongs in the other hand.

The bottom of the fusion crucible is tapped lightly on the steel table and the melt is swirled to ensure that it is liquid and of the right consistency. The melt is then poured (fig. 12) into the iron mold, after which the crucible is rapidly rotated vertically so that the liquid does not run down the sides of the crucible. After every two fusions are poured, the cover of the mold is advanced to prevent the solidifying slag from ejecting. After all fusions have been poured, the surface of the furnace is raked (fig. 13) and smoothed with hot powdered bone ash stored at the rear of the furnace.

After the crucibles and melts have cooled, the crucibles are examined for shot (discussed in the section "Refusions"), and the slag of the cooled melt is broken with a steel rod and hammer. The small amount of slag remaining on the lead button is removed by tapping it with the steel rod. The button is then transferred to a $50-\mathrm{ml}$ beaker marked with the last three digits of the sample number, and 10 percent $\mathrm{HCl}$ is added to about $0.25 \mathrm{in} .(0.5 \mathrm{~cm})$ over the button. The beaker is covered with a watch glass, placed on the edge of a hot plate, 


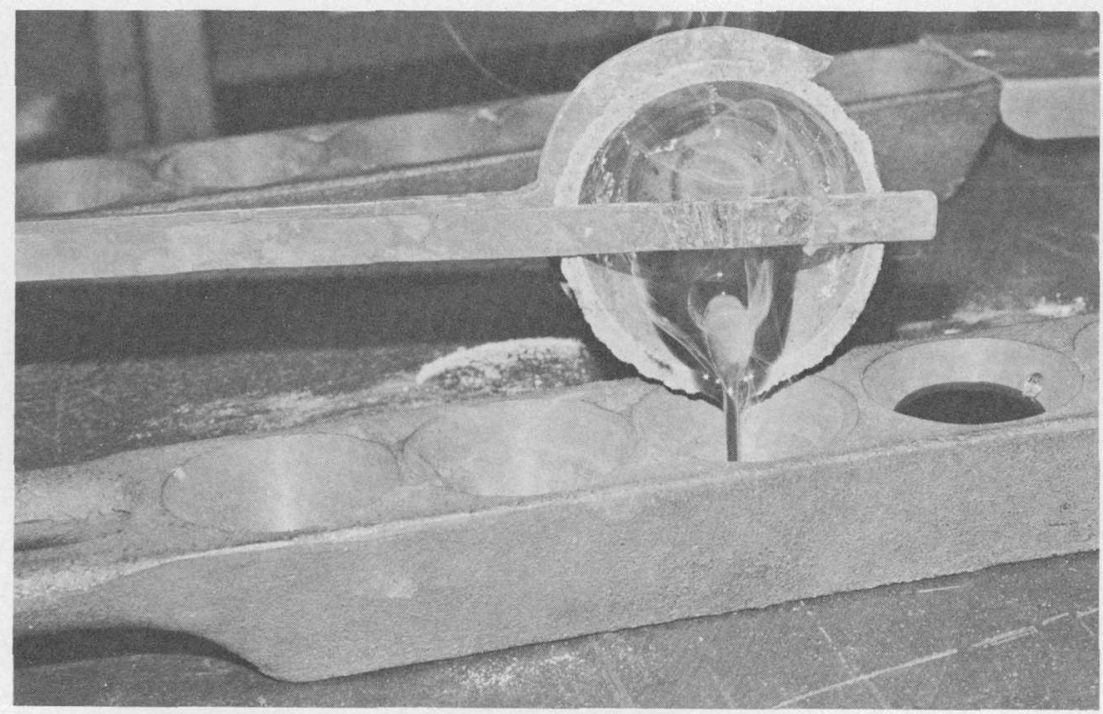

Figure 12. - Melt being poured into iron mold, using crucible-scorifier tongs. Note opaque glob of molten lead in crucible, which will constitute the button upon solidification.

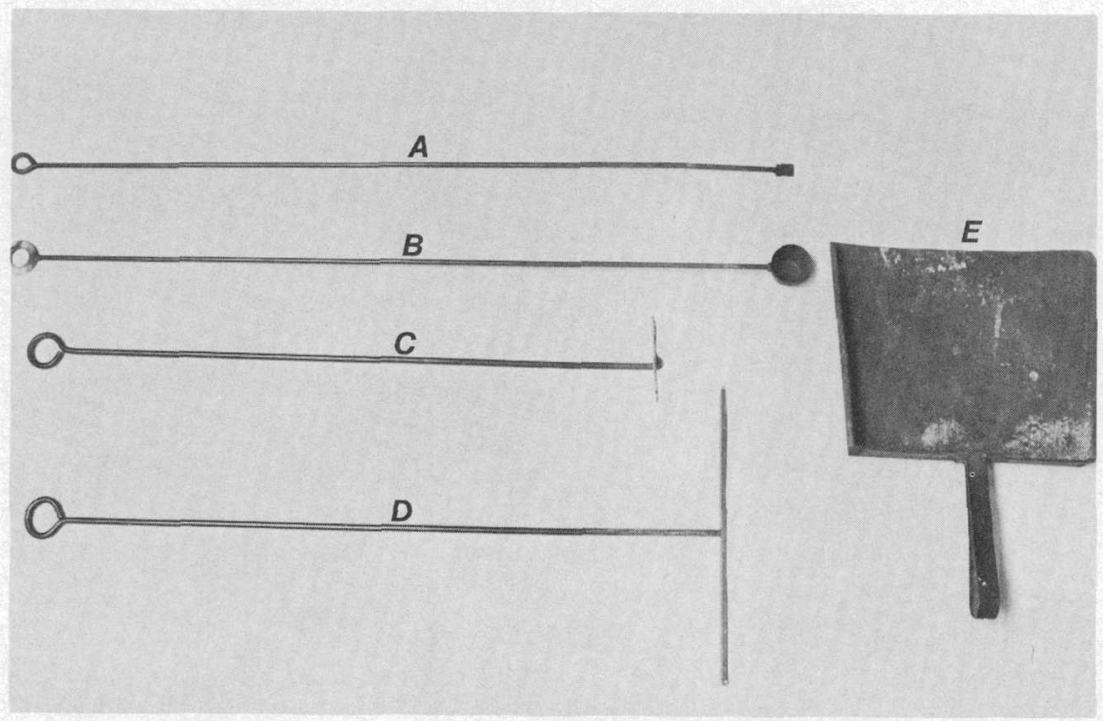

Figure 13. - Additional furnace tools. $A$, Furnace spatula used to convey one or more reagents to fusion crucible when deemed necessary; $B$, Furnace crucible used to transfer water to fusion crucible to prevent boilover; $C$, Hoe-shaped furnace scraper used in the event of spillover of molten sharge; $D$, Rake used to smooth powdered bone ash on bottom surface of furnace; $E$, Shovel, made of heavy gauge sheet steel, to receive spillover. 
and the contents allowed to digest for about 1-2 hours to remove the last traces of slag. The button is then rinsed and brushed under running water and shaped into a cube with a hammer and anvil (fig. 14). The corners are rounded slightly for convenience of handling (with button tongs, fig. 9). If the button appears somewhat brittle, it should

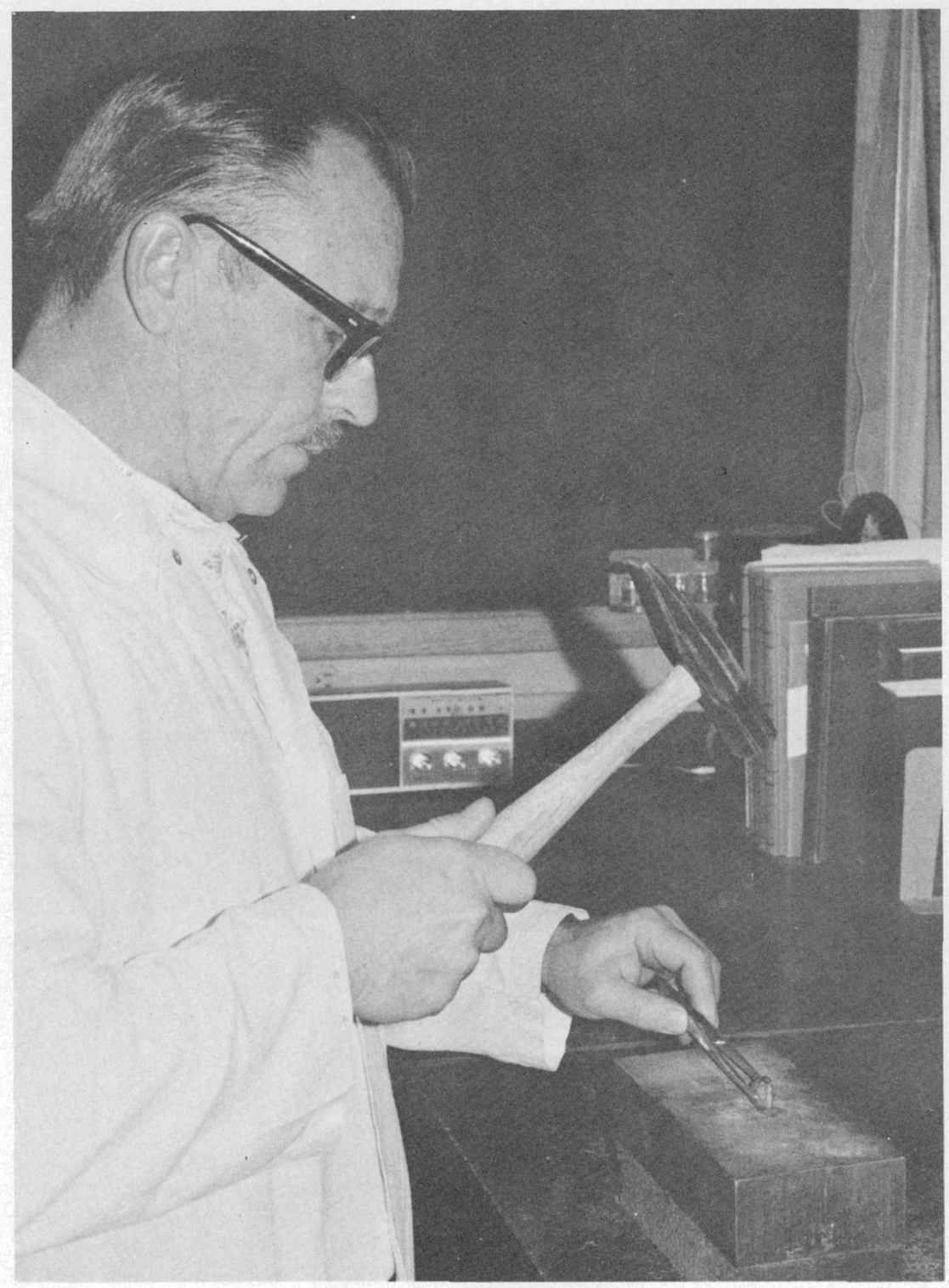

FIGURE 14. - Shaping lead button for cupellation. 
not be hammered more than necessary or it may flake and crack. The buttons are marked in pencil with the last three digits of the sample number and placed on a button tray, ready for cupellation (fig. 15).

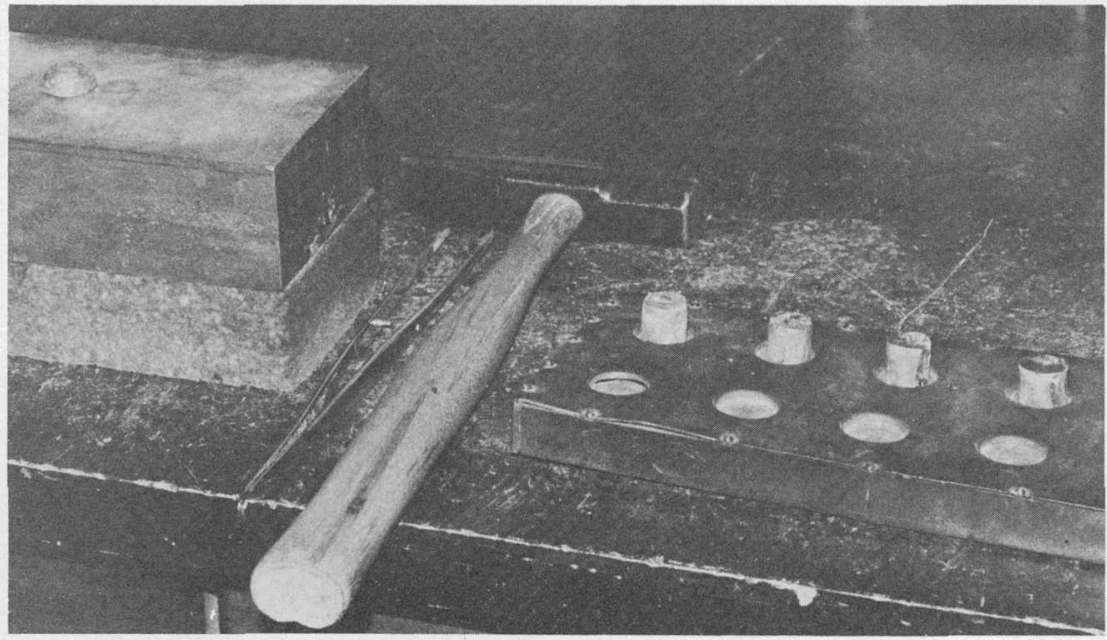

Figure 15. - Close-up view of lead buttons before (left) and after (right) shaping.

FUSION OF CHROMITE-BEARING SAMPLES USING AN AUXILIARY FLUX

Samples high in chromite such as chromitites, are very difficult, if not impossible, to fuse with a single charge as is done for other types of samples. The problem was solved in our laboratory by using an auxiliary flux in addition to the charge normally assigned for fusing highchromium-bearing samples. The technique involves making a charge consisting of $30 \mathrm{~g} \mathrm{Na}_{2} \mathrm{CO}_{3}, 35 \mathrm{~g} \mathrm{PbO}, 10 \mathrm{~g} \mathrm{SiO}_{2}, 30 \mathrm{~g} \mathrm{Na}_{2} \mathrm{~B}_{4} \mathrm{O}_{7}, 1-2 \mathrm{~g}$ $\mathrm{CaF}_{2}$, and $3.2 \mathrm{~g}$ flour plus $15 \mathrm{~g}$ of sample and the added noble metal in a " $30-g$ " fireclay crucible. The auxiliary flux is prepared by weighing $10 \mathrm{~g} \mathrm{Na}_{2} \mathrm{CO}_{3}, 5 \mathrm{~g} \mathrm{SiO}_{2}$, and $25 \mathrm{~g} \mathrm{Na}_{2} \mathrm{~B}_{4} \mathrm{O}_{7}$ in a " 20 - g" crucible and mixing the contents well. (See table 1.)

Both crucibles are placed in a preheated furnace, using a charging fork; the auxiliary flux is put in first. Usually, four samples are processed at a time, and all temperatures and techniques are the same as in the crucible fusion. However, the additional step of adding the melt of the auxiliary flux to the melt of the sample charge occurs at the end.

After the $32(17+15)$ minutes have elapsed with the temperature of the furnace at $1000^{\circ} \mathrm{C}$, the sample charge is removed from the furnace with the crucible-scorifier tongs and placed on the steel table. Immediately after this, the auxiliary flux is removed, and the melt is poured into the fused sample charge. The crucible, now containing both melts, is grabbed with the crucible-scorifier tongs, swirled a little 
(while still on the steel table) and then placed back into the furnace for an additional 5 minutes at the same temperature $\left(1000^{\circ} \mathrm{C}\right)$. If four samples are being processed, the timer should be set after the last crucible is placed in the furnace.

After 5 minutes have elapsed, the crucible is removed and about the first one-third of the melt (without lead) is poured into one hole of the mold, and the remaining two-thirds, containing the molten lead, is poured into a second hole. This is done because the volume of the melt is too large for one hole. After cooling, the slag of the lead-bearing mass is broken and the button is prepared as described in detail in the "Fusion" section.

The technique for fusing chromite concentrates or high-grade chromite ores varies slightly from the approach discussed previously for chromitite. Owing to the highly refractory nature of the material, 3 $\mathrm{g}$ of sample, instead of the routine $15 \mathrm{~g}$, is used for each of five fusions. (See table 1.) All five fusions may be carried out in the same fireclay crucible, provided that no cracks or leaks develop. To one of the charges $\mathrm{Ag}$ or $\mathrm{Au}$ is added to collect the other noble metals during cupellation. The flux used for each $3 \mathrm{~g}$ of sample consists of the following components: $30 \mathrm{~g} \mathrm{Na}_{2} \mathrm{CO}_{3}, 35 \mathrm{~g} \mathrm{PbO}, 10 \mathrm{~g} \mathrm{SiO}_{2}, 30 \mathrm{~g} \mathrm{Na}_{2} \mathrm{~B}_{4} \mathrm{O}_{7}, 1 \mathrm{~g}$ $\mathrm{CaF}_{2}$, and $3.5 \mathrm{~g}$ of flour mixed in a " 30 -g" crucible. In addition, the auxiliary flux is used in the same manner, as described in the first four paragraphs of this section. In order to obtain a single lead button for cupellation, the five buttons from the five fusions are combined in a scorifier, and the amount of lead is reduced by the technique of scorification described in a following section.

\section{PRELIMINARY FUSION}

A preliminary fusion is used primarily to determine the reducing power of an ore. A charge consisting of $3 \mathrm{~g}$ ore, $10 \mathrm{~g} \mathrm{Na}_{2} \mathrm{CO}_{3}, 46 \mathrm{~g} \mathrm{PbO}$, $3 \mathrm{~g} \mathrm{SiO}_{2}$, and $1 \mathrm{~g} \mathrm{Na}_{2} \mathrm{~B}_{4} \mathrm{O}_{7}$ (table 1 ) is prepared and mixed in a " $10-\mathrm{g}$ " fireclay crucible. The fusion is performed at a temperature of $1050^{\circ} \mathrm{C}$ for 15 minutes without using shielding crucibles. The techniques involved in obtaining the lead button from the solidified melt were described in a previous section. However, the step of cleaning the button with 10 percent $\mathrm{HCl}$ is omitted for the preliminary fusion. The calculations for determining the reducing power of the ore are discussed in the section "Theory of fire assaying."

\section{REFUSIONS}

Repeat fusions of a sample are conducted (usually with a different flux) when an undesirable fusion was obtained and sufficient sample is available. When the sample is insufficient, the slag from the first fusion can be reprocessed. 
Indications of an unsuccessful fusion are (a) the slag contains shot (globules of lead); (b) the melt is viscous and gives a sloppy pour; (c) the charge is too siliceous as is indicated by glassy streamers, or too basic which gives a muddy pour and a stony appearance. A kind of "too basic" slag is one high in litharge from which an insufficient amount of lead was reduced. This is recognized by its higher-thanaverage specific gravity and even acrystalling character. There are also unsuccessful fusions where the sample has not even decomposed.

Unsuccessful fusions usually fall into one or more of the categories just listed based on their pour and the nature of their slag. Knowing which flux components to alter and the proper amounts to use to obtain a successful fusion may require considerable thought and experimentation. In some instances generalities may be stated, but in others the problem is unique.

No specific set of conditions can unequivocally be stated for the cause of shot in the slag. Consequently, no generalities can be stated to avoid the production of shot. However, some hypotheses or observations may be or have been suggested. For example, if the melt is viscous it may cause the globules of lead, produced from the reduction of particles of $\mathrm{PbO}$, to remain in suspension and prevent them from combining to form the lead button. Or, the globules of lead may become coated and thus prevented from combining. Making the melt more fluid in the former instance may aid in the combining and collection of the lead globules. In the latter instance, the causes for coating of the lead globules require considerably more investigation. However, the addition of a considerable amount of $\mathrm{Na}_{2} \mathrm{~B}_{4} \mathrm{O}_{7},(30-35 \mathrm{~g})$, as in fusing chromite ores, seems to prevent coating of the globules in many cases.

When a viscous pour is evident, steps must be taken to increase its fluidity by increasing one or more flux components, frequently $\mathrm{Na}_{2} \mathrm{CO}_{3}$ or $\mathrm{PbO}$ or $\mathrm{Na}_{2} \mathrm{~B}_{4} \mathrm{O}_{7}$, but sometimes $\mathrm{SiO}_{2}$ or $\mathrm{CaF}_{2}$. If a highly siliceous pour is indicated, the usual treatment is to increase the $\mathrm{Na}_{2} \mathrm{CO}_{3}$ by $5-10 \mathrm{~g}$, and when the pour is too basic, to increase the $\mathrm{SiO}_{2}$ and $\mathrm{Na}_{2} \mathrm{~B}_{4} \mathrm{O}_{7}$. Both pours need additional $\mathrm{PbO}$ (about $20 \mathrm{~g}$ ).

If, during the pour and after cooling, material similar to the sample appears on the side of the fireclay crucible and in the slag, the sample obviously has not decomposed. This condition suggests that the proper flux may not have been selected. Further study and experimentation to select the proper flux will usually solve this problem. However, in a few instances, such as when fusing chromite concentrates, it may be necessary to decrease the size of the sample from the routine $15 \mathrm{~g}$ to $3 \mathrm{~g}$ to obtain an acceptable fusion. 
Occasionally, there may be a need for fusing used bone-ash cupels to retrieve any noble metals absorbed by the cupel when samples low in noble-metal content are being analyzed, one had forgotten to add a collector, and all the sample was used. First, the unsaturated part of the cupel is removed and discarded. The litharge-saturated part of the cupel (the sample) usually consists of about 50 percent bone ash and 50 percent litharge $(\mathrm{PbO})$. It is weighed and then ground with a steel mortar and pestle. If any sample sticks to the mortar it is removed by grinding a quantity of coarse silica equal to the amount required by the charge. The silica is then added to the charge.

To fuse the litharge-saturated part of the cupel, only the weight of the bone ash is considered when constituting the charge. To the fireclay crucible, add $\mathrm{Na}_{2} \mathrm{CO}_{3}$ equal to one and a half times the weight of bone ash, $\mathrm{Na}_{2} \mathrm{~B}_{4} \mathrm{O}_{7}$ equal to two-thirds of the weight of bone ash, $\mathrm{CaF}_{2}$ equal to half the weight, $\mathrm{SiO}_{2}$ equal to one-third the weight, flour for a 25-30 g lead button $(2.8-3.0 \mathrm{~g})$, and the entire sample plus the noble metal to be used as a collector. For example, the charge would work out as follows; all quantities are in grams:

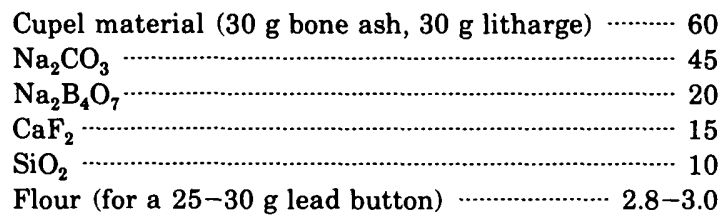

If the lead button obtained from the first fusion is small $(10-20 \mathrm{~g})$, add enough $\mathrm{PbO}$ to the charge to produce a $25-30 \mathrm{~g}$ lead button. Also, because bone ash is calcium phosphate the preceding formula may also be used to fuse calcium-phosphate samples.

\section{CUPELLATION}

The lead button obtained from the crucible fusion is treated by a process called cupellation to separate the noble metals from the lead. This consists of an oxidizing fusion in a porous vessel made of compressed bone ash called a cupel. The lead oxidizes rapidly to molten $\mathrm{PbO}, 98.5$ percent of which is absorbed by the cupel and 1.5 percent of which is volatilized. When this process has been carried to completion, the noble metals are left on the cupel in the form of a bead. The cupel itself may be regarded as a membrane permeable to molten litharge $(\mathrm{PbO})$ and impermeable to lead and the noble metals.

First, the size of the cupel is selected on the basis of the weight of the lead button. For buttons weighing $32 \mathrm{~g}$ or less, 1.5-in.-diameter (3.8-cm-diameter) cupels are used, and for buttons weighing $32-48 \mathrm{~g}$, 
1.75-in.-diameter (4.4-cm-diameter) cupels are used. Due to the intense heat of the furnace and for convenience of handling, no more than 18-24 buttons should be cupelled at a time.

The cupels are numbered with a diamond-tip pencil, using the last three digits of the sample number. They are then arranged in numerical order in rows of six on the cupel-charging tray (fig. 4) to correspond to the position taken by the same-numbered button on the button tray. While still on the tray the sample cupels, when $1.5 \mathrm{in}$. in diameter, are surrounded by a single row of shielding cupels (blank cupels) of the same size for the front row (rear of furnace) and sides. The larger size (1.75 in.) blank cupels are used as shields for the back row (nearest the furnace door). When all the sample cupels are $1.75 \mathrm{in}$. in diameter, all the surrounding shielding cupels are of that size. The shielding cupels are used to protect the sample cupels from drafts, thus reducing the dangers of "freezing" (lead oxide covering the molten lead and preventing further oxidation).

The cupels are then transferred to the cold furnace by means of the cupel charging tray and are placed about two-thirds the distance to the rear. The outermost cupel of each row is tapped lightly with the cupel tongs (fig. 9) so that all cupels are touching one another. The furnace door is closed, and the temperature is set for $800^{\circ} \mathrm{C}$. When this temperature is attained, a laboratory coat and asbestos gloves are worn, the furnace door is opened, and two rows of shielding scorifiers (scorifiers loaded with graphite electrodes) are placed in front of the cupels using the charging fork. The scorifiers with graphite aid in reducing the otherwise highly oxidizing atmosphere so that oxidation will proceed at a desirable rate. They also aid by heating the air which passes over them, preventing "freezing" of the buttons.

Following this, the furnace door is closed, and the temperature is raised to $1000^{\circ} \mathrm{C}$. When this temperature is attained, the button tray with buttons is placed on the furnace-door shelf. All the heat protection equipment is worn, and the buttons are transferred to the sample cupels using the button tongs (fig. 9). (See figs. 16, 17.) The door is closed for a few minutes then opened to see that the buttons are "open" (lead buttons become molten and red throughout).

When the buttons are "open," the furnace door is kept open and the temperature is decreased to $840^{\circ} \mathrm{C}$. It is desirable to decrease the temperature as rapidly as possible to avoid losses of the noble metals to the cupels. This can be accomplished readily by using the exhaust fan built into all modern furnaces to supplement natural draft. If the furnace is also equipped with a canopy-type exhaust hood, this also should be turned on. An air conditioner, in addition to both fans, is advantageous particularly in the summertime. All measures available to a laboratory to produce better ventilation in the room should be employed during this step of the cupellation. 


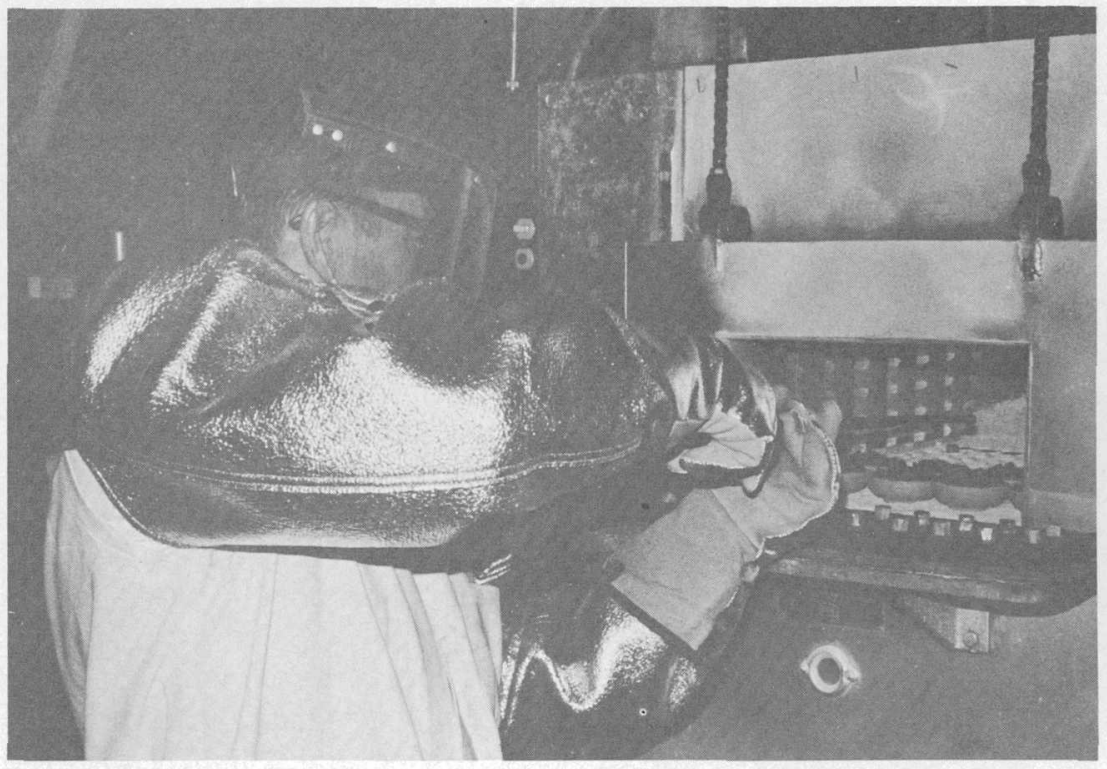

FIGURE 16. - Transferring buttons from button tray to hot cupels using button tongs. Note rows of shielding scorifiers in foreground and use of protective equipment.

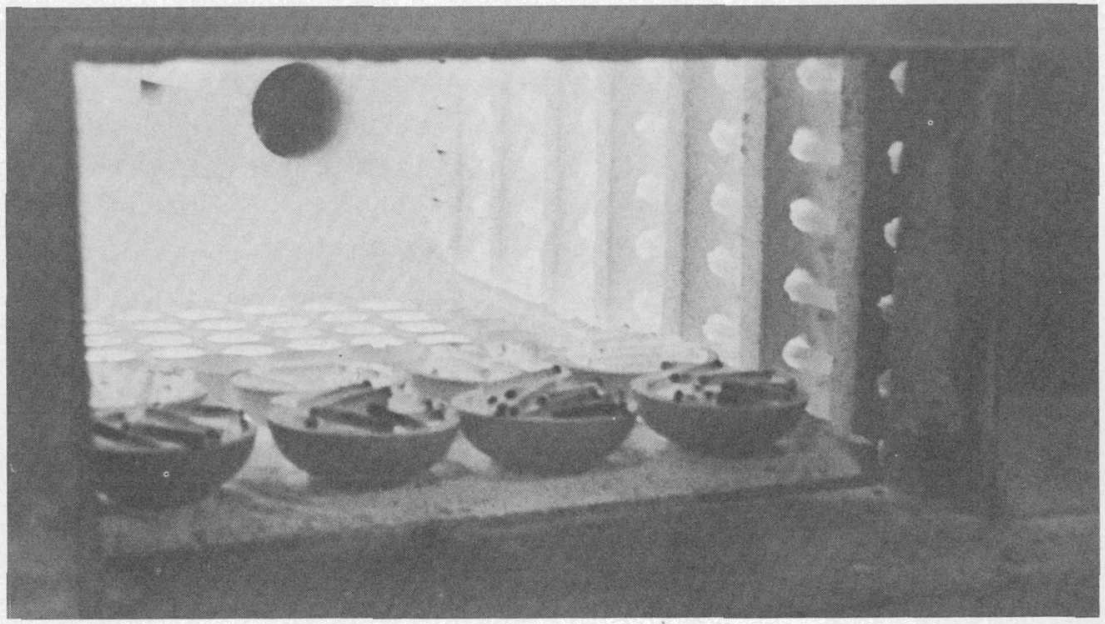

FiguRE 17. - Technique of cupellation showing buttons "open" and two rows of shielding scorifiers in foreground.

When the temperature has reached $840^{\circ} \mathrm{C}$, all fans are turned off, and the furnace door is raised to about $1.5 \mathrm{in} .(3.8 \mathrm{~cm})$ of the top so that one can observe the cupellation. If there is a mixture of small and 
large cupels, the temperature settings should be adjusted for the small cupels. The temperature is maintained at $840^{\circ} \mathrm{C}$ for $5-10$ minutes after the molten lead mass assumes a domelike appearance. Then it is raised to $860^{\circ} \mathrm{C}$ and held at this temperature for another $5-10$ minutes. After this it is raised to $880^{\circ} \mathrm{C}$ and held for the same period of time. After this time, or when the buttons have decreased in size to no less than $0.19-0.25$ in. $(0.5 \mathrm{~cm})$, the temperature is raised to $900^{\circ} \mathrm{C}$ and maintained at this temperature until all the lead is gone and only the beads remain. At times it may be necessary to increase the finishing temperature to $910^{\circ}-920^{\circ} \mathrm{C}$, especially when it is cold outdoors and a downdraft exists. One can determine this when he sees lead-oxide fumes coming through the opening set for the door. If this should occur, turn on the upper exhaust fan(s) to exhaust the fumes through the chimney.

After all the beads are obtained the furnace is turned off, and the scorifiers are removed with the charging fork. Then the back row (closest to the furnace door) and side rows of shielding cupels are removed, two at a time, with the cupel tongs (fig. 9) and placed on the steel table. Following this, the sample cupels with beads (fig. 18) are removed, and then the front row of shielding cupels is removed in the same way and placed beside the blank cupels. The furnace is raked smooth with bone ash, and the sample cupels are allowed to cool before weighing the beads (fig. 19).

The temperatures in this procedure are for the determination of platinum metals using gold as a collector. However, for the determination of gold, using silver as a collector, the cupellation procedure is the same except that the temperature is first lowered to $820^{\circ} \mathrm{C}$ and finished at $880^{\circ} \mathrm{C}$.
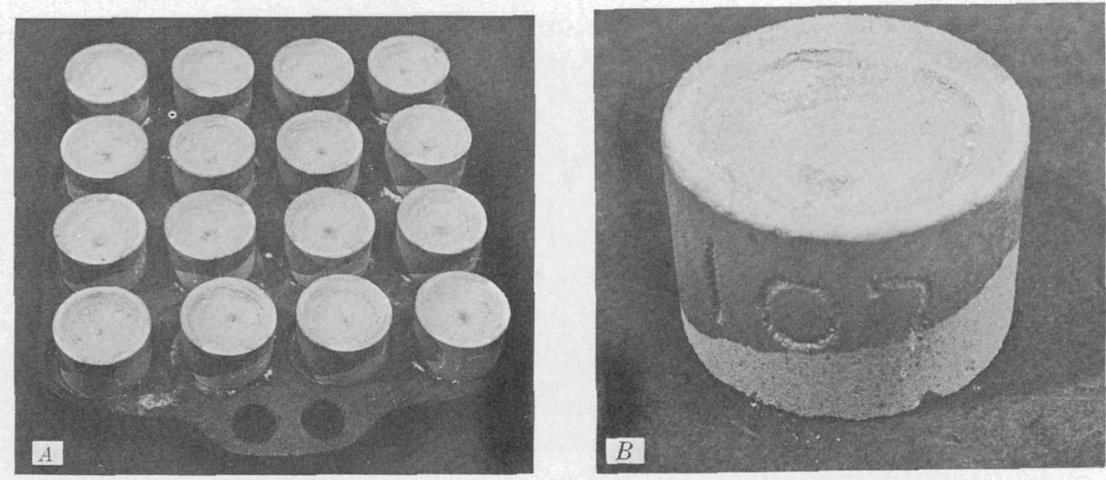

FIgURE 18. - Cupels bearing beads. $A$, Cupel tray holding 16 cupels with beads; $B$, Close-up view of a single cupel with litharge absorbed, showing bead and last three digits of sample number. 


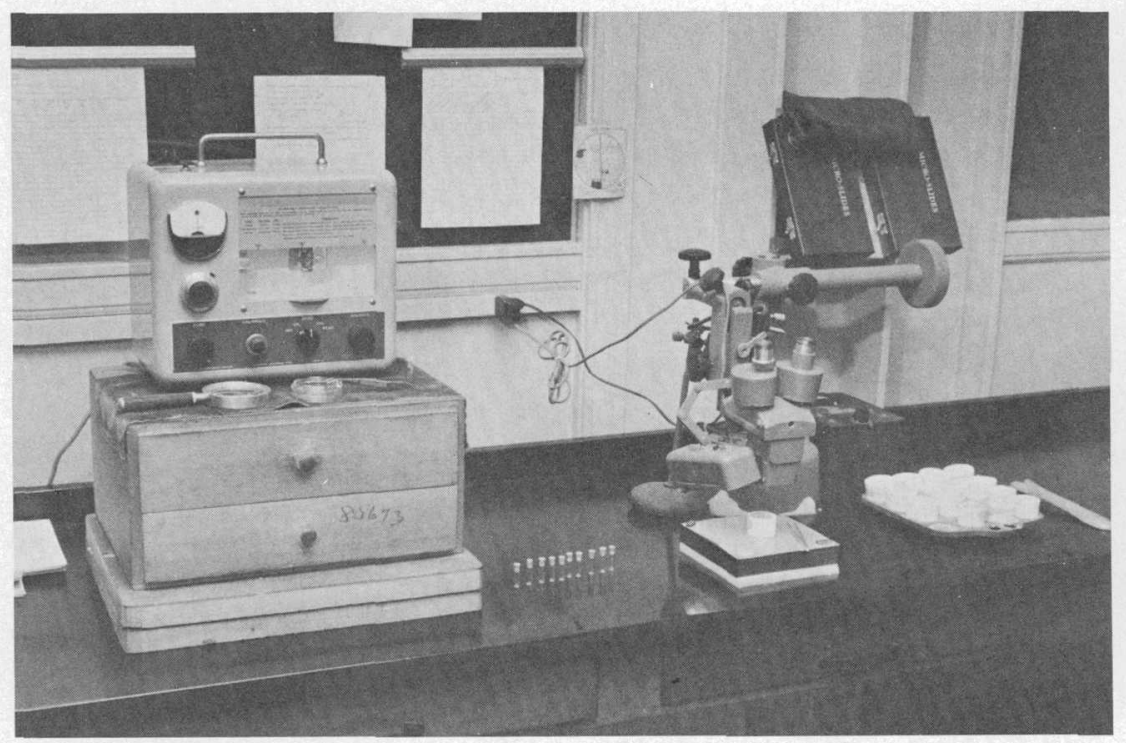

Figure 19. - Weighing room, showing a stereoscopic microscope (on right) for examining bead while still on the cupel and Cahn electrobalance (on left) used to weigh the bead.

When the sample contains major amounts of copper (more than 10 percent), caution should be exercised in cupelling the button. In one instance, the button "froze" during cupellation, and it was necessary to scorify the button obtained after a second fusion. Scorification helped to reduce the amount of copper in the button, resulting in a successful cupellation. However, in other instances where copper was in major amounts, as indicated by a semiquantitative spectrographic analysis, scorification was not necessary. This may be due to the relative amounts of copper in each sample. Other metals which alloy with lead may present similar problems and may require the same treatment.

\section{SCORIFICATION}

Scorification is an oxidizing fusion made in a shallow fireclay dish known as a scorifier (fig. 5). The technique is used almost exclusively in the Survey laboratory to decrease the amount of lead in large-sized buttons ( $>48 \mathrm{~g}$ ) for cupellation. Also, it has been used to combine and reduce the size of two or more buttons into a single button when two or more fusions of the same sample are necessary, such as in chromitebearing materials. Sometimes it may be necessary to go through two scorifications to decrease the amount of lead to achieve the desired result. The objective is to obtain a 25 - to 30 -g button. 
After the buttons have been cleaned of their slag, but not digested in 10 percent $\mathrm{HCl}$, they are weighed on the Mettler balance and each brought to a weight of $60 \mathrm{~g}$ using test lead. The contents are then transferred to 2.5-in. (6.4-cm) O.D. scorifiers. One gram of a 1:1 mixture of $\mathrm{Na}_{2} \mathrm{~B}_{4} \mathrm{O}_{7}$ and $\mathrm{SiO}_{2}$ is sprinkled on top of these contents $(2 \mathrm{~g}$ when the weight of lead exceeds $60 \mathrm{~g}$ ). If the combination of buttons exceeds a weight of $60 \mathrm{~g}$, a larger scorifier is used. (See table 2 for selecting the proper scorifier.)

The scorifiers are placed in the furnace which has been preheated to $1000^{\circ} \mathrm{C}$, using crucible-scorifier tongs and wearing asbestos gloves. The furnace door is closed, and the temperature is lowered to $950^{\circ} \mathrm{C}$. After a few minutes the furnace door is opened; if the lead is molten and exhibits a smooth red reflective color, the door is kept open. The iron mold to which the contents are to be transferred is placed on the furnace door to absorb heat. This is done to prevent a spill-out which might occur when a hot material is poured onto a cold surface.

As the scorification progresses, a layer of molten slag gradually covers the surface of the molten lead, starting from the edge of the scorifier (fig. 20). When the coverage is complete, the iron mold is removed using asbestos gloves and is placed on the steel table. Then the scorifier is removed using crucible-scorifier tongs, and the contents are poured into the iron mold. Sometimes the layer of molten slag does not cover the surface entirely but closes down to form a circle

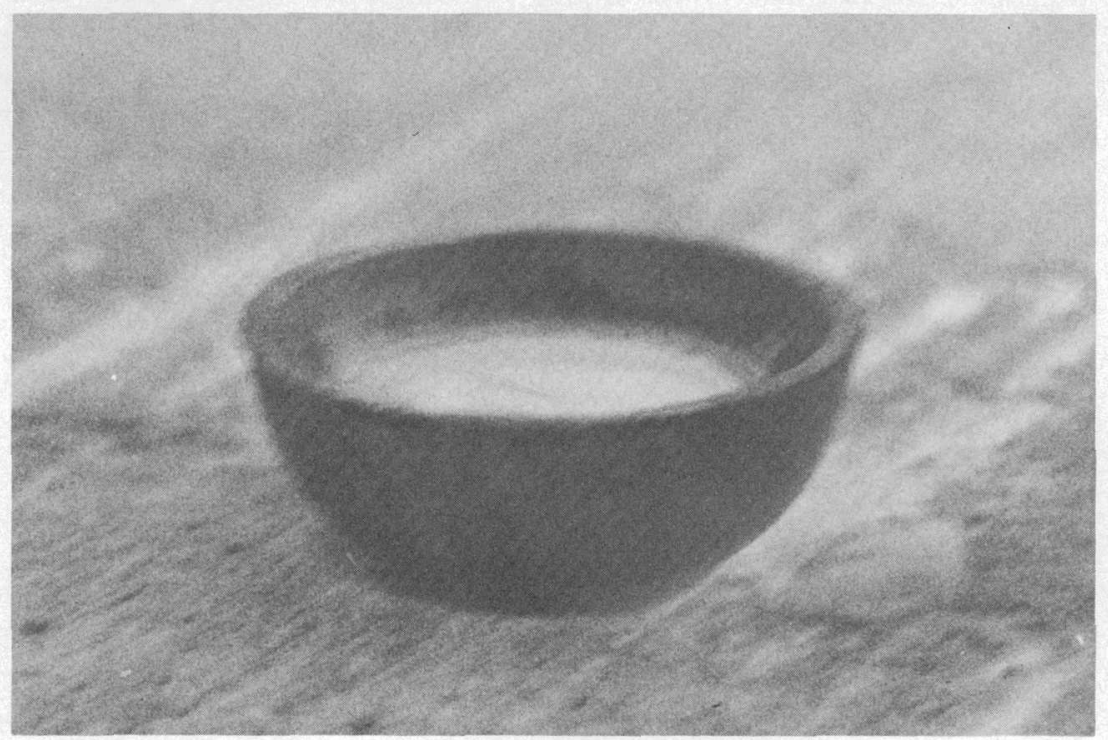

FiguRE 20. - Scorification. Layer of molten slag is shown forming from edge of scorifier. 
of about $0.5 \mathrm{in}$. (about $1 \mathrm{~cm}$ ) in diameter. If this condition persists for a few minutes, the scorifier is removed and the melt poured. The contents are allowed to cool, and the slag is removed from the lead button which is shaped for cupellation, as described previously.

It is important to select the proper size scorifier in attempting to diminish an amount of lead exceeding $48 \mathrm{~g}$. Table 2 gives the relation between scorifier size and the amount of lead (button plus test lead) necessary to obtain buttons weighing $25-30 \mathrm{~g}$.

\begin{tabular}{|c|c|}
\hline $\begin{array}{c}\text { Scorifier } \\
(0 . D .=\text { in. })\end{array}$ & $\begin{array}{l}\text { Weight of lead required } \\
\text { (g) }\end{array}$ \\
\hline $\begin{array}{l}2.5(6.4 \mathrm{~cm}) \\
3(7.6 \mathrm{~cm}) \\
3.5(8.9 \mathrm{~cm})\end{array}$ & $\begin{array}{l}\ldots \ldots \\
\ldots \ldots\end{array}$ \\
\hline
\end{tabular}

\section{METHODS OF ANALYSIS}

The following methods for the determination of the noble metals are those most commonly used by the U.S. Geological Survey. The methods described were developed either within our laboratory or are modifications of other methods which appeared in the literature and were designed to facilitate the determination of the noble metals in a large number of samples.

With the exception of the acid-digestion method for silver, most methods use fire-assay techniques in combination with other techniques to achieve the desired sensitivity. In addition, fire assay serves to eliminate essentially all the associated gangue minerals, thereby drastically reducing the possibilities of interference. The methods described in the following pages employ extensive use of atomic absorption spectroscopy, emission spectrographic analysis, and neutronactivation analysis.

\section{DETERMINATION OF GOLD BY FIRE ASSAY AND ATOMIC ABSORPTION}

The method for determining gold routinely is described in detail by Huffman, Mensik and Riley (1967). The fusion and cupellation steps of the fire-assay technique for gold are the same as those for the platinum metals, except that the temperature in the cupellation step is decreased to $820^{\circ} \mathrm{C}$ and finished at $880^{\circ} \mathrm{C}$.

For the determination of gold, $2 \mathrm{mg}$ of silver alloyed with lead in precut lengths of rod are added to the charge in the fireclay crucible before fusion of the sample. The silver-lead rod is obtainable commercially under the trade name Herman Inquarts (Van Waters \& Rogers). Silver is important in this procedure for three reasons: (1) It has a protective effect and thus reduces gold losses during the cupella- 
tion step (Bugbee, 1940, p. 107); (2) it allows trace amounts of gold to be easily transferred from the cupel to a suitable container for analysis; and (3) the addition of silver provides a silver-gold bead that is easily dissolved. The ratio of silver to gold should be greater than 3:1 to effect dissolution of the bead. Beads having lower ratios of silver to gold may be difficult to dissolve even in aqua regia. When a sample is known from a previous semiquantitative spectrographic analysis to contain sufficient silver, such addition is unnecessary; conversely, for samples that contain considerable gold, the addition of more than 2 $\mathrm{mg}$ of silver may be necessary to attain this 3:1 ratio. The silver-gold bead is routinely weighed to permit an estimate of the combined gold and silver content of the ore. Silver can then be determined by difference after gold is determined by atomic absorption. The difference method for silver is reliable down to as little as about 20 ppm. Gold can be determined as low as 50 ppb using a 15 -g sample.

\section{PROCEDURE FOR GOLD}

1. Transfer the silver-gold bead obtained by fire assay to a $50-\mathrm{ml}$ beaker.

2. Add $5 \mathrm{ml}$ of (1:1) $\mathrm{HNO}_{3}$, cover with watchglass and digest on a steam bath for 30 minutes. Uncover, rinse cover with 2-3 ml of distilled water and evaporate the solution to about 4-5 ml.

3. Remove beaker from steam bath and add $8 \mathrm{ml}$ of concentrated $\mathrm{HCl}$. Cover and let stand for 20 minutes without heat. Place beaker with cover on steam bath and digest until the solutions turn a pale yellow (about 30-60 minutes). Uncover, wash watchglass with distilled water, and allow to evaporate to hard dryness.

4. Add $9 \mathrm{ml}$ of concentrated $\mathrm{HCl}$, cover, and digest on the steam bath until all salts are in solution. Then add about $15 \mathrm{ml}$ of distilled water, cover, and digest an additional 30 minutes.

5. Cool. Quantitatively transfer the solution to a Pyrex culture tube by washing beaker with about $10 \mathrm{ml}$ of distilled water. Add $2 \mathrm{ml}$ of 48-percent $\mathrm{HBr}$, mix, add $10 \mathrm{ml}$ of MIBK and shake tube for 1 minute.

6. Using a water-saturated solution of MIBK as a reference blank, gold is determined at a wavelength of $2428 \AA$ by aspirating the organic phase of both the unknown sample and standard solutions into an atomic absorption spectrophotometer. The absorption is noted and the concentration of gold in the organic phase of the unknown sample is read from the analytical curve established by the standards. The gold content of the sample in parts per million is then calculated as follows:

Gold, in ppm, in organic phase $\times 10 \mathrm{ml}$

Weight of sample, in grams 
PREPARATION OF STANDARDS AND THE ANALYTICAL CURVE

1. Prepare a stock solution containing $\mathbf{4 0 0} \mathrm{ppm}$ gold by dissolving $0.2000 \mathrm{~g}$ of pure gold metal in a $400-\mathrm{ml}$ covered beaker using 30 $\mathrm{ml}$ of aqua regia. Remove the cover and evaporate to dryness on a steam bath. Then heat on a hotplate until fumes from $\mathrm{HNO}_{3}$ are no longer present. Add $250 \mathrm{ml}$ of (1:1) $\mathrm{HCl}$ to the beaker and digest on the steam bath to dissolve the gold salts. Transfer the solution to a $500-\mathrm{ml}$ volumetric flask and dilute to volume with distilled water.

2. Dilute the stock solution to obtain solutions containing 40 , 4 , and 2 ppm gold in 25 percent $(\mathrm{v} / \mathrm{v}) \mathrm{HCl}$.

3. Prepare standards for analysis containing $0.2,0.4,2,4,8$, and 10 ppm Au in the organic phase by adding $2 \mathrm{ml}$ of the $2 \mathrm{ppm}, 2 \mathrm{ml}$ of the $4 \mathrm{ppm}, 1 \mathrm{ml}$ of the $40 \mathrm{ppm}, 2 \mathrm{ml}$ of the $40 \mathrm{ppm}, 4 \mathrm{ml}$ of the 40 $\mathrm{ppm}$ and $5 \mathrm{ml}$ of the $40 \mathrm{ppm}$ gold solutions, respectively, to a series of culture tubes. Add $2 \mathrm{ml}$ of 48 percent $\mathrm{HBr}$ to each and adjust the volume to about $40 \mathrm{ml}$ with distilled water. Add $20 \mathrm{ml}$ of MIBK and shake for 1 minute to extract the gold into the organic phase. The standards are stored in this manner.

4. The analytical curve is established by the standards by plotting percent absorption versus concentration on linear coordinates.

When the gold content of the sample is exceptionally high producing a bead weighing more than $20 \mathrm{mg}$, the gold and silver, if present, are determined gravimetrically by parting procedures common to fireassay methods as described by Bugbee (1940, p. $126-133)$.

\section{DETERMINATION OF GOLD BY FIRE ASSAY \\ AND NEUTRON-ACTIVATION ANALYSIS}

A detailed discussion of this method which is applicable to the determination of gold in silicates is given by Rowe and Simon (1968). The method consists of irradiating 1-g samples for 10 hours in a neutron flux of $5 \times 10^{12} \mathrm{n} / \mathrm{cm}^{2} / \mathrm{s}$ and allowed to decay for 10 days. The samples are then carried through classical fire-assay separations in the presence of $20-50 \mathrm{mg}$ of gold carrier, and the 2.7 -day ${ }^{198} \mathrm{Au}$ having a photopeak at $0.413 \mathrm{MeV}$ is counted in a gamma-ray spectrophotometer. The fire-assay technique provides for the radiochemical separation of gold with a minimum of operator attention. However, the ${ }^{110 \mathrm{~m}} \mathrm{Ag}$ gamma photopeak at $0.445 \mathrm{MeV}$ interferes with the determination when the silver concentration in the sample is more than 10 $\mathrm{ppm}$. The method has a detection limit of $0.05 \mathrm{ppb}$ using a 1-g sample.

REAGENTS AND APPARATUS

Fire-assay flux: Thoroughly mix $1000 \mathrm{~g} \mathrm{PbO}, 100 \mathrm{~g} \mathrm{Na}_{2} \mathrm{CO}_{3}, 20 \mathrm{~g}$ $\mathrm{Na}_{2} \mathrm{~B}_{4} \mathrm{O}_{7}$, and $50 \mathrm{~g}$ flour. 
Gold carrier: Weigh $20-50 \mathrm{mg}$ of gold metal ( $\pm 0.1 \mathrm{mg}$ accuracy) and place it in a numbered vial.

Counting equipment: A pulse-height-analyzer system using a four-input mixer-router coupled to four 3-by 3-in. NaI(Tl) well-type crystals which collect four spectra simultaneously.

\section{PROCEDURE}

1. Grind each sample to less than 100 mesh and carefully mix and quarter. Weigh and seal $1 \mathrm{~g}$ of each sample in a 0.4-dram polyethylene vial. Irradiate 16 samples plus four standards (monitors, described later), for 10 hours in a neutron flux of $5 \times 10^{12} \mathrm{n} / \mathrm{cm}^{2} / \mathrm{s}$. Store samples for 10 days to allow decay of the short-lived isotopes (primarily 15 -hour ${ }^{24} \mathrm{Na}$ and 2.6 -hour ${ }^{56} \mathrm{Mn}$ ).

2. For each sample place $80 \mathrm{~g}$ of fire-assay flux into a fire-assay crucible and make a depression in the flux to receive the sample.

3. Transfer the irradiated sample to the depression in the flux and mix.

4. Add the gold carrier; cover the mixture with a layer of borax glass and cover the crucible with a scorifying dish.

5. Place the crucible in a fire-assay furnace. Fuse the contents and cupel the lead button applying the fire-assay techniques as detailed in previous sections, with one exception: Break the slag away from each lead button in a plastic bag to prevent scattering of glass.

6. The gold bead obtained after cupellation is weighed and placed in a plastic vial.

7. Collect the spectra. After several days collect another set of spectra to verify the decay of 2.7 -day ${ }^{198} \mathrm{Au}$.

8. Standards (monitors) are treated the same as samples.

9. Calculate the area of each $0.413 \mathrm{MeV}$ photopeak for ${ }^{198} \mathrm{Au}$ (Covell, 1959) and adjust data to zero decay time.

10. Determine the amount of gold in each sample using the equation:

$$
W_{s}=W_{m} \frac{A_{s} / Y_{s}}{A_{m} / Y_{m}},
$$

where $W$ is the weight of gold, $A$ is the activity, and $Y$ is the carrier yield; the subscripts $s$ and $m$ refer to sample and monitor, respectively.

\section{PREPARATION OF STANDARDS}

1. Prepare standard gold-stock solutions: Solution $A$ (1000 ppm $\mathrm{Au}$ - Dissolve $1.00 \mathrm{~g}$ of gold metal in aqua regia and dilute to 1 $\mathrm{L}$ with $2 \mathrm{M} \mathrm{HCl}$. Solution $B(10 \mathrm{ppm} \mathrm{Au}$ - Dilute $5.00 \mathrm{ml}$ of solution $A$ to $500 \mathrm{ml}$ with $2 M \mathrm{HCl}$. Solution $B$ is stable for 
several months. Solution $C(0.5 \mathrm{ppm} \mathrm{Au})$ - Dilute $5.00 \mathrm{ml}$ of solution $B$ to $100 \mathrm{ml}$ with $2 \mathrm{M} \mathrm{HCl}$. Solution $C$ should be prepared each time monitors are prepared.

2. Prepare each standard (flux monitor) containing $50 \mathrm{ng}$ of gold by accurately pipetting $0.1 \mathrm{ml}$ of solution $C$ onto $0.2 \mathrm{~g}$ of spectrographic grade silica in a 0.4 -dram polyethylene vial. Dry overnight and seal the vial.

\section{DETERMINATION OF GOLD IN PHOSPHATES BY ACTIVATION ANALYSIS USING EPITHERMAL NEUTRONS}

When the entire reactor spectrum of neutrons (thermal plus epithermal) is used to irradiate phosphate samples, high levels of 16 -day ${ }^{32} \mathrm{P}$ are formed (Rowe, 1973). The use of epithermal neutron irradiation permits the determination of gold while reducing the amount of ${ }^{32} \mathrm{P}$ formed thereby reducing the overall radioactivity generated. The isolation and use of epithermal neutrons is made possible by placing the sample-containing polyethylene vials in cadmium cylinders. Cadmium absorbs neutrons below an energy level of $0.4 \mathrm{eV}$ which is the upper limit for thermal neutrons and, therefore, allows only epithermal neutrons to go through to irradiate the samples.

\section{PROCEDURE}

1. Weigh $1 \mathrm{~g}$ of each sample into a 0.4 -dram polyethylene vial.

2. Prepare monitors containing $50 \mathrm{ng}$ of gold by accurately pipetting $0.2 \mathrm{ml}$ of a solution containing $250 \mathrm{ng}$ of gold $/ \mathrm{ml}$ onto $0.2 \mathrm{~g}$ of spectrographic-grade silica in a 0.4 -dram vial.

3. Heat-seal the vails and place them in cadmium cylinders $(1 \mathrm{~mm}$ thick).

4. Irradiate 10 samples plus four monitors together for 30 minutes using a thermal flux of $5 \times 10^{12} \mathrm{n} / \mathrm{cm}^{2} / \mathrm{s}$.

5. After cooling overnight, both samples and monitors are processed and the gold determined, using the fire assay-radiochemical method of Rowe and Simon (1968).

\section{DETERMINATION OF SILVER BY ACID DIGESTION}

A method for determining silver is described in detail by Huffman, Mensik, and Rader (1966). In this method fire-assay techniques are not employed. The procedure consists of digesting the sample with nitric acid, centrifuging the diluted solution, and aspirating the clear solution into the flame of an atomic absorption spectrophotometer for measurement of silver at a wavelength of $3284 \AA$ Silver ranging in concentration from $1 \mathrm{ppm}$ to about $9000 \mathrm{ppm}$ (or about 0.03 to $250 \mathrm{oz}$ troy/ton) 
can be determined without preliminary separations even in the presence of high concentrations of diverse elements.

\section{PROCEDURE FOR SILVER}

1. Transfer $1 \mathrm{~g}$ of rock powder to a $100-\mathrm{ml}$ beaker.

2. Moisten the sample with $2 \mathrm{ml}$ of distilled water and add $10 \mathrm{ml}$ of concentrated nitric acid. Cover the beaker with a watchglass.

3. After any vigorous reaction subsides, place the covered beaker on a hotplate and boil the solution gently so that some refluxing occurs for about 15 minutes. Swirl the beaker occasionally to mix the solution and alleviate bumping.

4. Cool, add $25 \mathrm{ml}$ of distilled water, and heat on a steam bath for about 30 minutes.

5. Transfer the solution and any insoluble material to a $50-\mathrm{ml}$ volumetric flask, cool, dilute to volume, and mix.

6. Decant about half the solution into a $50-\mathrm{ml}$ centrifuge tube and centrifuge it for about 5 minutes.

7. Using the standard operating conditions for silver given in the Perkin-Elmer instruction manual, aspirate the clear solution into the flame of an atomic absorption spectrophotometer and measure the percent absorption of silver at a wavelength of $3284 \AA$.The concentration of the silver in the sample is then read from an analytical curve established by the following standards.

PREPARATION OF STANDARDS AND THE ANALYTICAL CURVE

1. Prepare a stock solution containing $500 \mathrm{ppm}$ silver by dissolving $0.1000 \mathrm{~g}$ of silver metal with $10 \mathrm{ml}$ of nitric acid and diluting to a 200-ml volume with distilled water.

2. Prepare the following standards by diluting the stock solution to contain $0.0200,0.1000,0.5000,1.000,2.500$, and $5.000 \mathrm{ppm}$ of silver in 5-percent nitric acid.

3. The analytical curve is established by the standards by plotting percent absorption versus concentration on linear coordinates.

If the silver content of the sample is exceptionally high, fire-assay techniques may be employed as in the gold analysis. The silver and gold, if present, are determined gravimetrically by parting procedures common to fire assay methods as described by Bugbee (1940, p. $126-133)$.

\section{DETERMINATION OF PALLADIUM, PLATINUM, AND RHODIUM BY FIRE-ASSAY PRECONCENTRATION AND EMISSION SPECTROGRAPHY}

The method used for the quantitative determination of palladium, platinum, and rhodium is described in detail by Haffty and Riley 
$(1968,1971)$ and is the one most frequently used by the U.S. Geological Survey. The method is relatively free from extensive sample manipulations, is adequately sensitive, and can determine all three elements in a single procedure.

The method consists of preconcentrating these three platinum metals in a gold bead, using the fire-assay techniques described in previous sections, dissolving the bead in aqua regia, and diluting to volume with $1 \mathrm{M} \mathrm{HCl}$. Then $200 \mu \mathrm{l}$ of this solution are transferred to a pair of flat-top graphite electrodes, the solution is evaporated under a heat lamp, and the residue is analyzed by optical emission spectrography. The method can determine palladium down to as little as $4 \mathrm{ppb}$, platinum to $10 \mathrm{ppb}$, and $\mathrm{Rh}$ to $5 \mathrm{ppb}$.

\section{REAGENTS}

Gold wire. 99.999 percent pure and 0.005 in. $(0.13 \mathrm{~mm})$ in diameter. Prepare in lengths weighing $1 \mathrm{mg}$ (approx. $4.5 \mathrm{~mm}$ in length).

Lead foil (silver free). $0.008-0.016$ in. $(0.2-0.4 \mathrm{~mm})$ thick. Prepare in pieces 0.5 in. $(1.3 \mathrm{~cm})$ square to receive the $1-\mathrm{mg}$ gold wire. The piece of foil is sharply folded at the center with flat-nosed pliers. The fold is then opened, the gold wire, after being weighed on a Cahn electrobalance, is transferred from the pan to the center of the crease. The fold is closed on the wire and again folded at the center to give a thickness of four layers. All edges are then crimped with pliers to ensure enclosure of the wire. This lead envelope is added as the last step in the preparation of the fusion mixture.

Gold stock solution. Prepare from the same stock of gold wire to contain $10 \mathrm{mg} / \mathrm{ml}$ by dissolving $100 \mathrm{mg}$ of gold wire in $1 \mathrm{ml}$ of aqua regia in a $10-\mathrm{ml}$ volumetric flask and dilute to volume with $1 \mathrm{M} \mathrm{HCl}$.

Apiezon N solution. Dissolve $5.0 \mathrm{~g}$ of Apiezon $\mathrm{N}$ in $1 \mathrm{~L}$ of petroleum ether (certified, A.C.S. bp $30^{\circ}-60^{\circ} \mathrm{C}$, sp. gr. 0.625 to 0.650 at $25^{\circ} \mathrm{C}$ ). Molybdenum internal standard solution. Prepare a solution containing $4 \mathrm{mg} \mathrm{Mo} / \mathrm{L}$ by dissolving $920 \mathrm{mg}$ of ammonium molybdate $\left[\left(\mathrm{NH}_{4}\right)_{6} \mathrm{Mo}_{7} \mathrm{O}_{24} \cdot 4 \mathrm{H}_{2} \mathrm{O}\right]$ in about $200 \mathrm{ml}$ of water in a $500-\mathrm{ml}$ volumetric flask. Then add $\mathrm{HCl}$ and dilute to volume with water to give a molybdenum concentration of $1000 \mathrm{mg} / \mathrm{L}$ in a $2 M \mathrm{HCl}$ solution. Dilute successively with $2 \mathrm{M} \mathrm{HCl}$ to obtain a solution of $4 \mathrm{mg}$ Mo/L.

\section{PROCEDURE}

1. Thoroughly mix, in a " 30 -g" fireclay crucible, $15 \mathrm{~g}$ of ground sample with a suitable assay flux (table 1) to which the lead envelope containing the gold wire had been added.

2. Fuse the contents and cupel the lead button applying the fireassay techniques as detailed in previous sections. 
3. Carefully transfer the gold bead obtained after cupellation to the pan of a Cahn electrobalance and weigh. The weight of the gold wire added to the flux initially is compared with the weight of the bead obtained. Any sizeable gain (or slight loss) is noted and aids in calculating the dilution factor if the weight has substantially increased.

4. Then transfer the bead to a $1-\mathrm{ml}$ volumetric flask and add $0.1 \mathrm{ml}$ of aqua regia ( $3: 1$ hydrochloric acid:nitric acid) and allow to stand overnight at room temperature (usually 13 beads are prepared at a time). To ensure complete dissolution of the bead, heat the solution for 15-20 minutes on a steam bath the following morning.

5. After the bead has dissolved, add $0.05 \mathrm{ml}$ of the molybdenum internal standard solution to the 1-ml flask and dilute the mixture to volume with $1 \mathrm{M} \mathrm{HCl}$. This gives a concentration of about $1000 \mathrm{mg} \mathrm{Au} / \mathrm{L}$ and $0.2 \mathrm{mg} \mathrm{Mo/L}$.

6. If the weight of the bead has substantially increased and the shape or color indicate the presence of platinum metals, transfer the bead to a $2-\mathrm{ml}$ volumetric flask and add $0.2 \mathrm{ml}$ of aqua regia. After dissolution of the bead, dilute the mixture to volume with $1 \mathrm{MHCl}$. Then dilute aliquots of this mixture and add proportional amounts of the gold stock solution and internal standard solution so that the final dilution contains about 1000 $\mathrm{mg} \mathrm{Au} / \mathrm{L}$ and $0.2 \mathrm{mg} \mathrm{Mo/L}$ as in the standards.

PREPARATION OF STANDARDS

1. Prepare standard stock solutions of each element to contain $\mathbf{1 0 0 0}$ mg of the element per liter in $2 \mathrm{M} \mathrm{HCl}$. This is accomplished by dissolving $267.2 \mathrm{mg}$ of ammonium chloropalladite $\left[\left(\mathrm{NH}_{4}\right)_{2} \mathrm{PdCl}_{4}\right]$, $227.5 \mathrm{mg}$ of ammonium chloroplatinate $\left[\left(\mathrm{NH}_{4}\right)_{2} \mathrm{PtCl}_{6}\right]$, and 385.6 mg of ammonium chlororhodite $\left[\left(\mathrm{NH}_{4}\right)_{3} \mathrm{RhCl}_{6} \cdot 11 / 2 \mathrm{H}_{2} \mathrm{O}\right]$ in $50 \mathrm{ml}$ of water in a $100-\mathrm{ml}$ volumetric flask, adding $16.4 \mathrm{ml}$ of concentrated $\mathrm{HCl}$, and diluting to volume with water.

2. Serially dilute these stock solutions with $2 \mathrm{M} \mathrm{HCl}$ to give concentrations of $100,50,25,10, \ldots 0.5 \mathrm{mg} / \mathrm{L}$.

3. Prepare the standards for analysis by transferring $0.2 \mathrm{ml}$ of the gold stock solution to each of nine $2-\mathrm{ml}$ volumetric flasks. To these add $0.1 \mathrm{ml}$ each of the palladium, platinum, and rhodium solutions. In addition to this add $0.1 \mathrm{ml}$ of the molybdenum internal standard solution. The resulting standards contain palladium, platinum, and rhodium in concentrations of 50,5 , $2.5,1.25,0.5, \ldots 0.025 \mathrm{mg} / \mathrm{L}$ in solutions containing $1000 \mathrm{mg}$ $\mathrm{Au} / \mathrm{L}$ and $0.2 \mathrm{mg} \mathrm{Mo} / \mathrm{L}$. 


\section{SPECTROGRAPHIC ANALYSIS}

1. First, the edge of each 0.25 -in. (6.35-mm) flat-top graphite electrode is rounded by rubbing on a piece of Whatman No. 42 ashless filter paper $11.0 \mathrm{~cm}$ in diameter. This is done to prevent the spark portion of the excitation from concentrating on the edge of the electrode.

2. For each exposure of the samples and standards two electrodes are waterproofed with four drops each of the Apiezon N solution. Each photographic plate contains the exposures of 13 samples in duplicate, plus 9 standards and 1 iron bead to calibrate the emulsion.

3. Then $100 \mu$ l of the unknown sample or the standard, both containing the internal standard, are added to each electrode in $50-\mu \mathrm{l}$ increments and evaporated by means of a heat lamp. Therefore, each exposure consists of exciting the residue of $200 \mu \mathrm{l}$ of solution using the apparatus and operating conditions listed in table 3 .

4. The iron bead used for plate calibration is arced at 5 amps d.c. and exposed for 21 seconds at a transmission of 3.8 percent. The iron lines and relative intensities used for plate calibration were selected from a list of homologous lines and are shown in table 4. The calibration curve is established by plotting transmission (ordinate) versus intensity (abscissa) on log-log paper.

5. After the photographic plate has been processed, transmittance measurements of selected analytical and internal standard lines (table 5) are obtained by means of a microphotometer. From the calibration curve, intensity values are obtained for the standards which are used in constructing the analytical curves. The analytical curves are established by plotting the ratio of the intensities of the analytical and internal standard lines versus concentration on logarithmic coordinates. The concentrations of the elements in the unknown samples are read from the analytical curves.

6. The absolute weight of metal is calculated from the volume of solution in which the bead was dissolved. This weight is then divided by the weight of sample taken to give parts per million or parts per billion in the sample.

\section{DETERMINATION OF PLATINUM AND PALLADIUM BY FIRE-ASSAY PRECONCENTRATION AND NEUTRON-ACTIVATION ANALYSIS}

A detailed description of this method is given by Rowe and Simon (1971) and employs the irradiation of the silver bead after fire-assay preconcentration. Post-irradiation fire-assay radiochemistry was used 
TABLE 3. - Apparatus and spectrographic operating conditions

Excitation source - intermittent d.c. arc. Primary power source - full-wave rectified 280-V, 60-cycle power supply — initiated by a high-voltage condensed spark synchronized to initiate each half cycle.

Radio-frequency current .................

Initiating circuit parameters:

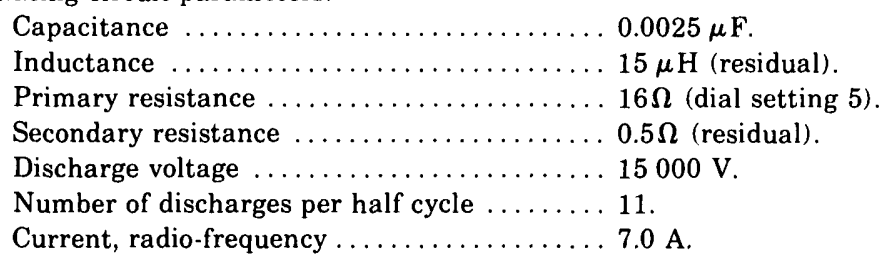

Spectrograph - folded, 3-m Rowland circle-mounted grating with 21000 lines/in. giving a reciprocal linear dispersion of $4 \AA \mathrm{mm}$ in the first order.

Wavelength region $\ldots \ldots \ldots \ldots \ldots \ldots \ldots, 2400-3600 \AA$.

Slitwidth $\ldots \ldots \ldots \ldots \ldots \ldots \ldots \ldots \ldots \ldots, 40 \mu$.

Illumination $\ldots \ldots \ldots \ldots \ldots \ldots \ldots \ldots$ Arc image focused on grating.

Analytical gap ....................

Transmission ....................... 80 percent.

Exposure ......................... 20 s.

Emulsion $\ldots \ldots \ldots \ldots \ldots \ldots \ldots \ldots \ldots \ldots \ldots \ldots$ Kodak SA -1.1

Electrodes $\ldots \ldots \ldots \ldots \ldots \ldots \ldots \ldots \ldots \ldots \ldots \ldots \ldots \ldots \ldots \ldots$ ASTM type $\mathrm{C}-3$.

' Use of any brand name in this report is for identification purposes only and does not imply endorsement by the U.S. Geological Survey.

TABLE 4. - Iron lines used for plate calibration

\begin{tabular}{crrr}
\hline $\begin{array}{c}\text { Fe line } \\
(\AA)\end{array}$ & Intensity & $\begin{array}{c}\text { Fe line } \\
(\AA)\end{array}$ & Intensity \\
\hline 3157.89 & & 3217.38 & 165 \\
3175.45 & 125 & 3222.07 & 625 \\
3178.02 & 94 & 3225.99 & 770 \\
3196.93 & 470 & 3239.44 & 285 \\
3205.40 & 210 & 3251.24 & 62 \\
3215.94 & 225 & 3268.24 & 29 \\
\hline
\end{tabular}

TABLE 5. - Analytical lines used in determination of palladium, platinum and rhodium |The Mo $2816.15 \AA$ line was used as internal standard line throughout]

\begin{tabular}{|c|c|c|}
\hline Element & $\begin{array}{c}\text { Analytical line } \\
(\AA)\end{array}$ & $\begin{array}{c}\text { Concentration range } \\
\text { based on analytical } \\
\text { curve }(\mathrm{mg} / \mathrm{L})\end{array}$ \\
\hline $\mathrm{Pd}$ & $\begin{array}{l}3242.70 \\
3404.58\end{array}$ & $\begin{array}{r}0.05-5.0 \\
0.025-0.5\end{array}$ \\
\hline $\mathrm{Pt}$ & 2659.45 & $0.125-5.0$ \\
\hline $\mathrm{Rh}$ & $\begin{array}{l}2490.77 \\
3396.85 \\
3434.89 \\
\end{array}$ & $\begin{array}{c}0.125-5.0 \\
0.05-5.0 \\
0.05-1.25\end{array}$ \\
\hline
\end{tabular}


by the same authors for the determination of gold. The method consists of adding 1 Herman Inquart (approximately $100 \mathrm{mg}$ of lead wire containing 2 percent silver) to $10-20 \mathrm{~g}$ of sample mixed with a suitable flux in a fire-assay crucible. The contents are fused, and the lead buttons obtained are cupelled to retrieve the silver and the two platinum metals if present. The silver beads are then irradiated for $12-16$ hours at a neutron flux of $5 \times 10^{12} \mathrm{n} / \mathrm{cm}^{2} / \mathrm{s}$. The practical limits of detection are $0.5 \mathrm{ppb}$ for each metal.

\section{REAGENTS}

Dimethylglyoxime. Prepare a 2 percent $w / v$ solution of dimethylglyoxime in reagent-grade alcohol.

Tin (II) chloride. Prepare a 10 percent $\mathrm{w} / \mathrm{v}$ solution in 50 percent $\mathrm{v} / \mathrm{v}$ $\mathrm{HCl}$. Add sponge tin.

Pt-, Pd-, Au-, and Ag-carrier solutions. Prepare solutions containing $10 \mathrm{mg}$ of the metal $/ \mathrm{ml}$ in $2 \mathrm{M} \mathrm{HCl}$.

Platinum wash solution. Prepare a solution containing 1 percent tin (II) chloride and 1 percent $\mathrm{AgCl}$ in $6 \mathrm{M} \mathrm{HCl}$.

\section{PROCEDURE}

1. Thoroughly mix $10-20 \mathrm{~g}$ of sample with a suitable assay-flux in a fire-assay crucible and add 1 Herman Inquart.

2. Fuse the contents and cupel the lead button applying the fireassay techniques as detailed in previous sections.

3. Wrap the silver beads in aluminum foil and irradiate for 12-16 hours at a flux of $5 \times 10^{12} \mathrm{n} / \mathrm{cm}^{2} / \mathrm{s}$ and allow to decay for at least 4 hours.

4. Dissolve the silver beads with nitric acid in disposable plastic beakers, add carriers $(10 \mathrm{mg}$ of $\mathrm{Pd}, 10 \mathrm{mg}$ of $\mathrm{Pt}$, and $10 \mathrm{mg}$ of $\mathrm{Au}$ ) and evaporate the solutions to dryness twice with aqua regia to achieve exchange of radioactive $\mathrm{Pt}, \mathrm{Pd}$, and $\mathrm{Au}$ with their carriers.

5. Add $1 \mathrm{ml}$ of $\mathrm{HCl}$ and $0.5 \mathrm{ml}$ of $\mathrm{HNO}_{3}$, heat to dissolve the salts, and dilute to $20 \mathrm{ml}$.

6. Add $2 \mathrm{ml}$ of silver carrier, filter, discard the silver chloride precipitate, and repeat this step twice more.

7. Add $15 \mathrm{ml}$ of $\mathrm{HCl}$ and a few drops of $\mathrm{HNO}_{3}$ to make the solution 4 $M$ in $\mathrm{HCl}$ and extract ${ }^{198} \mathrm{Au}$ and ${ }^{199} \mathrm{Au}$ with two 40 -ml portions of ethyl acetate rejecting the organic phase.

8. Add $10 \mathrm{mg}$ of gold carrier and extract again, repeating the extractions until the organic phase is colorless.

9. Dilute to about $100 \mathrm{ml}$ so that the solution is $2 \mathrm{Min} \mathrm{HCl}$. Add $5 \mathrm{ml}$ of the dimethylglyoxime solution to precipitate palladium as the dimethylglyoximate. Centrifuge and reserve the supernatant liquid for the separation of platinum. 
10. Dissolve the palladium dimethylglyoximate in a few drops of $\mathrm{HNO}_{3}$, dilute to $30 \mathrm{ml}$, and add $5 \mathrm{ml}$ of the dimethylglyoximate solution to reprecipitate palladium.

11. Centrifuge and wash the precipitate with $1 \mathrm{M} \mathrm{HCl}$. Reject the washings, filter off the precipitate on a tared filter paper or glass fiber circle, dry at $110^{\circ} \mathrm{C}$ and weigh.

12. Mount on an aluminum planchet and count.

13. Transfer the supernatant liquid (from the first precipitation of palladium) to a $250-\mathrm{ml}$ separatory funnel. Add $1 \mathrm{ml}$ of the dimethylglyoxime solution and extract with $10-\mathrm{ml}$ portions of carbon tetrachloride until the organic phase is colorless, rejecting the organic phase.

14. Add $5 \mathrm{ml}$ of $\mathrm{HCl}$ to make the solution $3 \mathrm{M}$ in that acid. Add $1 \mathrm{ml}$ of 5 percent hydroxylamine hydrochloride solution, $5 \mathrm{ml}$ of 10 percent tin (II) chloride and allow to stand for a few minutes.

15. Extract the platinum with two $30-\mathrm{ml}$ portions of ethyl acetate. Wash the combined ethyl acetate extracts twice with $10 \mathrm{ml}$ of the platinum wash solution rejecting the washings.

16. Evaporate the ethyl acetate and destroy organic material with nitric acid. Evaporate twice with aqua regia, and twice with a few drops of $\mathrm{HCl}$ to drive off nitrates.

17. Add $30 \mathrm{ml}$ of $2 \mathrm{M} \mathrm{HCl}$ and heat.

18. Add magnesium turnings to precipitate platinum metal and heat to coagulate the precipitate.

19. Filter on a glass fiber or Millipore circle and mount on a planchet using a Mylar cover.

20. Count samples and standards on a $\mathrm{NaI}(\mathrm{Tl})$ crystal and qualitatively examine the gamma-ray spectrum for radiochemical purity.

21. Because of the low concentration of $\mathrm{Pt}$ and $\mathrm{Pd}$ in rocks, betacounting is used. Place planchets in the sample changer of a proportional beta-counter. Adjust the counting time and maximum counts to provide a statistically suitable number of counts, yet permitting a reasonable frequency of changes. Count $\mathrm{Pt}$ for 12 days and $\mathrm{Pd}$ for 7 days or until counts approach background.

22. After counting the $\mathrm{Pt}$, remove the filter circle, precipitate and treat with $10 \mathrm{ml}$ of aqua regia and $1 \mathrm{ml}$ of $\mathrm{HF}$ in a $250-\mathrm{ml}$ disposable beaker to dissolve the $\mathrm{Pt}$. Evaporate to dryness on a steam bath.

23. Add $5 \mathrm{ml}$ of aqua regia and heat to dissolve the salts. Add copper sulfate and cadmium sulfate to provide a final concentration of 0.5 percent of $\mathrm{Cu}$ and $\mathrm{Cd}$ and dilute to volume.

24. Determine the chemical yield of Pt by the atomic absorption procedure of Schnepfe and Grimaldi (1969). 
1. Prepare standard stock solutions of platinum and palladium containing $1000 \mathrm{ppm}$ in 2 percent $\mathrm{v} / \mathrm{v} \mathrm{HCl}$ by dissolution of the metals or the ammonium chlorosalts. Prepare dilute solutions by dilution with 2 percent $\mathrm{v} / \mathrm{v} \mathrm{HCl}$.

2. Prepare standards for analysis by evaporating $1 \mathrm{ml}$ of a solution containing $2 \mu \mathrm{g}$ each of $\mathrm{Pt}$ and $\mathrm{Pd}$ on silica and process as for the samples.

\section{DETERMINATION OF PALLADIUM AND PLATINUM BY ATOMIC ABSORPTION}

This method is described in detail by Schnepfe and Grimaldi (1969). It consists of preconcentrating palladium and platinum in a gold bead using fire-assay techniques followed by atomic absorption to determine their concentration. A buffer solution of cadmium and copper sulfates is added to the bead solution to minimize or remove the effects of interfering elements, and it also enhances the sensitivity for the determination of both $\mathrm{Pd}$ and $\mathrm{Pt}$. The limit of determination for each metal is about $60 \mathrm{ppb}$ in a 20 -g sample.

\section{REAGENTS}

Gold wire. 99.999 percent pure and $0.1 \mathrm{~mm}$ in diameter. Prepare in lengths weighing $2.5 \mathrm{mg}$.

Gold solution. Prepare from the same stock of gold wire a gold chloride solution containing $2.5 \mathrm{mg}$ of gold $/ \mathrm{ml}$ in 1 percent $\mathrm{v} / \mathrm{v}$ hydrochloric acid.

Mixed cadmium-copper solution. Dissolve $57.0 \mathrm{~g}$ of cadmium sulfate $\left(3 \mathrm{CdSO}_{4} \cdot 8 \mathrm{H}_{2} \mathrm{O}\right)$ and $98.2 \mathrm{~g}$ of copper sulfate pentahydrate in a mixture of $500 \mathrm{ml}$ of $\mathrm{HCl}$ and $300 \mathrm{ml}$ of water. Dilute to $1 \mathrm{~L}$ with water.

\section{PROCEDURE}

1. Thoroughly mix $15-30 \mathrm{~g}$ of ground sample with a suitable assayflux in a fire-assay crucible and add $2.5 \mathrm{mg}$ of gold.

2. Fuse the contents and cupel the lead button applying the fireassay techniques as detailed in previous sections.

3. Transfer the gold bead obtained on cupellation to a small beaker and add $2 \mathrm{ml}$ of aqua regia. Allow the mixture to stand overnight at room temperature and heat it on a steam bath for about 15 minutes the following morning to ensure dissolution of the bead.

4. Evaporate the solution to dryness on a steam bath, add $1 \mathrm{ml}$ of $\mathrm{HCl}$ (1:1), and again evaporate the solution to dryness. Repeat. 
5. Add $1 \mathrm{ml}$ of the cadmium-copper solution, warm briefly to dissolve the salts, and transfer the solution to a $5-\mathrm{ml}$ volumetric flask. Dilute to volume with water.

6. Using a Perkin-Elmer Model 303 atomic absorption spectrophotometer set at 3405 Åfor palladium and 2659 Afor platinum, the concentrations of these two metals are determined by reference to the appropriate analytical curve.

PREPARATION OF STANDARDS AND THE ANALYTICAL CURVES

1. Prepare standard stock solutions of palladium and platinum from the metals or the ammonium chlorosalts containing $1.000 \mathrm{mg}$ of metal per milliliter in 2 percent $\mathrm{v} / \mathrm{v} \mathrm{HCl}$.

2. Prepare other solutions by diluting these stock solutions by factors of 10 with 2 percent $\mathrm{v} / \mathrm{v} \mathrm{HCl}$.

3. Prepare standards for analysis and also blanks, both containing $2.5 \mathrm{mg}$ of gold and $1 \mathrm{ml}$ of the cadmium-copper solution in $5 \mathrm{ml}$ total volume.

4. The analytical curve is established for each element by the standards by plotting absorbance versus concentration on linear coordinates.

\section{DETERMINATION OF IRIDIUM AND RUTHENIUM BY FIRE-ASSAY AND NEUTRON-ACTIVATION ANALYSIS}

Iridium and ruthenium are among the most challenging of the noble metals in regard to their determination. This is due to their very low concentration in most samples and their complex chemical behavior during analysis. The method of Greenland, Rowe, and Dinnin (1971) has been improved by J. J. Rowe (oral comm., 1975) by using highresolution $\mathrm{Ge}(\mathrm{Li})$ detectors instead of $\mathrm{NaI}(\mathrm{Tl})$ detectors so that ${ }^{103} \mathrm{Ru}$ can be determined in addition to ${ }^{192} \mathrm{Ir}$ in the same gamma-ray spectrum after fire-assay radiochemistry. $\mathrm{Ge}(\mathrm{Li})$ detectors also obviate the need for coincidence counting thereby reducing the counting time to 1 hour, whereas previously it was 24 hours. The simplification and increased efficiency of these counting procedures make the present method more applicable to geochemical problems. Although ${ }^{103} \mathrm{Ru}$ is formed as a fission product of uranium and may interfere with the determination when uranium is significantly high, the method can be applied to samples which contain relatively low uranium and high ruthenium as in chromites. Every microgram of $U$ upon fission produces $0.14 \mu \mathrm{g}$ of ${ }^{103} \mathrm{Ru}$ (Erdtmann, 1972). The method can determine Ir to $0.1 \mathrm{ppb}$ and $\mathrm{Ru}$ to $40 \mathrm{ppb}$ using a 0.1 -g sample.

When the uranium content in the sample is in sufficient amount to render the determination of ruthenium impractical by the procedure 
outlined later, a modification of the method by Koda (1970) is applied. The method consists of volatilizing ruthenium as the tetroxide and collecting it on a piece of polyethylene film prior to irradiation. The film is then irradiated, and the ruthenium is determined by counting using a $\mathrm{Ge}(\mathrm{Li})$ detector. The gamma-ray spectra are clean, and ruthenium can be determined down to $10 \mathrm{ppb}$, using a 0.1-g sample.

\section{REAGENTS AND APPARATUS}

Fire-assay flux. A mixture consisting of 29 percent $\mathrm{Na}_{2} \mathrm{CO}_{3}, 9$ percent $\mathrm{SiO}_{2}, 16$ percent $\mathrm{Na}_{2} \mathrm{~B}_{4} \mathrm{O}_{7}, 42$ percent $\mathrm{PbO}$, and 4 percent flour.

Platinum-rhodium (13 percent) or pure platinum wire used as collector. Prepare in lengths weighing $50 \mathrm{mg}$.

Iridium carrier solution. Prepare a solution containing $10 \mathrm{mg}$ of the metal per milliliter in $2 \mathrm{M} \mathrm{HCl}$.

Counting equipment. $\mathrm{Ge}(\mathrm{Li})$ detector coupled to a multichannel analyzer to collect the gamma-ray spectra.

\section{PROCEDURE}

1. Seal $0.1 \mathrm{~g}$ of powdered sample ( $-100 \mathrm{mesh}$ ) and standards (monitors) in mini-polyethylene vials, irradiate for 2 hours in a neutron flux of $5 \times 10^{13} \mathrm{n} / \mathrm{cm}^{2} / \mathrm{s}$, and allow to decay for 7-10 days. Usually 30 samples and 5 standards are irradiated at a time.

2. Transfer the irradiated sample or standard with vial to a " $30-\mathrm{g}$ " fireclay crucible and mix with $75 \mathrm{~g}$ of flux, $2-5 \mathrm{mg}$ of iridium as carrier, and $50 \mathrm{mg}$ of platinum-rhodium or pure platinum wire.

3. Place the crucible in a fire-assay furnace. Fire the contents and cupel the lead button applying the fire-assay techniques as detailed in previous sections.

4. Transfer the Pt-Rh-Ir bead, obtained after cupellation and containing most of the noble metals, to a sealed small polyethylene container for counting.

5. Count the beads of both samples and standards and determine ${ }^{192} \mathrm{Ir}$ using the gamma photopeaks at $0.296,0.316$, and 0.469 $\mathrm{MeV}$ and ${ }^{103} \mathrm{Ru}$ at $0.497 \mathrm{MeV}$.

\section{PREPARATION OF STANDARDS (MONITORS)}

1. Prepare standard stock solutions of iridium and ruthenium containing $1 \mathrm{ppm}$ and $10 \mathrm{ppm}$ respectively in 2 percent $\mathrm{v} / \mathrm{v} \mathrm{HCl}$ by dissolution of the ammonium chlorosalts.

2. Prepare standards (monitors) for analysis to contain $100 \mathrm{ng}$ of $\mathrm{Ir}$ and $1000 \mathrm{ng}$ of $\mathrm{Ru}$ by evaporating $0.1 \mathrm{ml}$ of each stock solution on 50-100 $\mathrm{mg}$ of pure silica and process as for samples. 
3. The low concentration standards for iridium described by Grimaldi and Schnepfe (1970) are also used as secondary standards.

\section{DETERMINATION OF THE NOBLE METALS AND COPPER BY A COMBINATION MINI-FIRE-ASSAY NEUTRON-ACTIVATION ANALYSIS PROCEDURE}

A procedure used sparingly by the U.S. Geological Survey is described by Millard and Bartel (1971) and determines Pd, Pt, Au, Ru, $\mathrm{Os}$, and Ir in a single geological sample using a scaled-down fire-assay technique combined with neutron-activation analysis. Since 1971, Millard and Bartel have expanded the procedure to include the determination of $\mathrm{Ag}$ and $\mathrm{Cu}$. The expanded procedure consists of irradiating 0.5- to 1-g samples in sealed quartz ampoules for 160 hours in a neutron flux of $6 \times 10^{12} \mathrm{n} / \mathrm{cm}^{2} / \mathrm{s}$ followed by an irradiation of 7 hours using a neutron flux of $2 \times 10^{13} \mathrm{n} / \mathrm{cm}^{2} / \mathrm{s}$. After 16 hours of decay, the ampoule is cleaned in hot, concentrated $\mathrm{HNO}_{3}$, opened, and the sample powder poured into a zirconium crucible $(35 \mathrm{ml})$ containing the following carriers: $10 \mathrm{mg} \mathrm{Ru}, 10 \mathrm{mg}$ Os, $3 \mathrm{mg} \mathrm{Pd}, 0.1 \mathrm{mg} \mathrm{Au}, 0.01 \mathrm{mg} \mathrm{Ir}, 10$ $\mathrm{mg} \mathrm{Ag}$, and $5 \mathrm{mg} \mathrm{Cu}$. Five grams of $\mathrm{Na}_{2} \mathrm{O}_{2}$ are added, and the mixture is first sintered for 5 minutes and then fused for 5 minutes over a Meker burner. While the mixture is still in the fusion state, $0.15 \mathrm{~g}$ of graphite is added to destroy the remaining peroxide. After the melt is cooled and has solidified, a mini-fire-assay technique is used to collect the noble metals and $\mathrm{Cu}$ in a $1 \mathrm{~g}$ lead button. After the crucible is allowed to cool, $6 \mathrm{~N} \mathrm{HCl}$ is added slowly to dissolve everything but the lead.

The lead button is then fused for 4 minutes with $4 \mathrm{~g} \mathrm{Na}_{2} \mathrm{O}_{2}$ and 400 $\mathrm{mg} \mathrm{NaOH}$ in the same zirconium crucible over a Meker burner. After cooling, the fusion cake is slurried with $30 \mathrm{ml} \mathrm{H}_{2} \mathrm{O}$ and transferred to a distillation flask. The chemical treatments and manipulations are summarized by the flow diagram in figure 21 .

When Pt and Au are in about the same concentration or when Pt exceeds the concentration of $\mathrm{Au}$ in the same sample, radioactive ${ }^{199} \mathrm{Au}$ is formed from the irradiation of $\mathrm{Pt}$ in a far greater ratio than from gold itself. For this reason ${ }^{199} \mathrm{Au}$ is counted for the determination of $\mathrm{Pt}$ using the gamma photopeak at $0.158 \mathrm{MeV}$. Also, $\mathrm{Pt}$ is not added as a carrier because isotopic exchange exists between the gold carrier added and ${ }^{199} \mathrm{Au}$.

The advantage of the procedure is the ability to determine all the noble metals - with the exception of rhodium - on a single sample when a limited amount is available. However, the procedure should be used only when a select small number of samples are to be analyzed. 


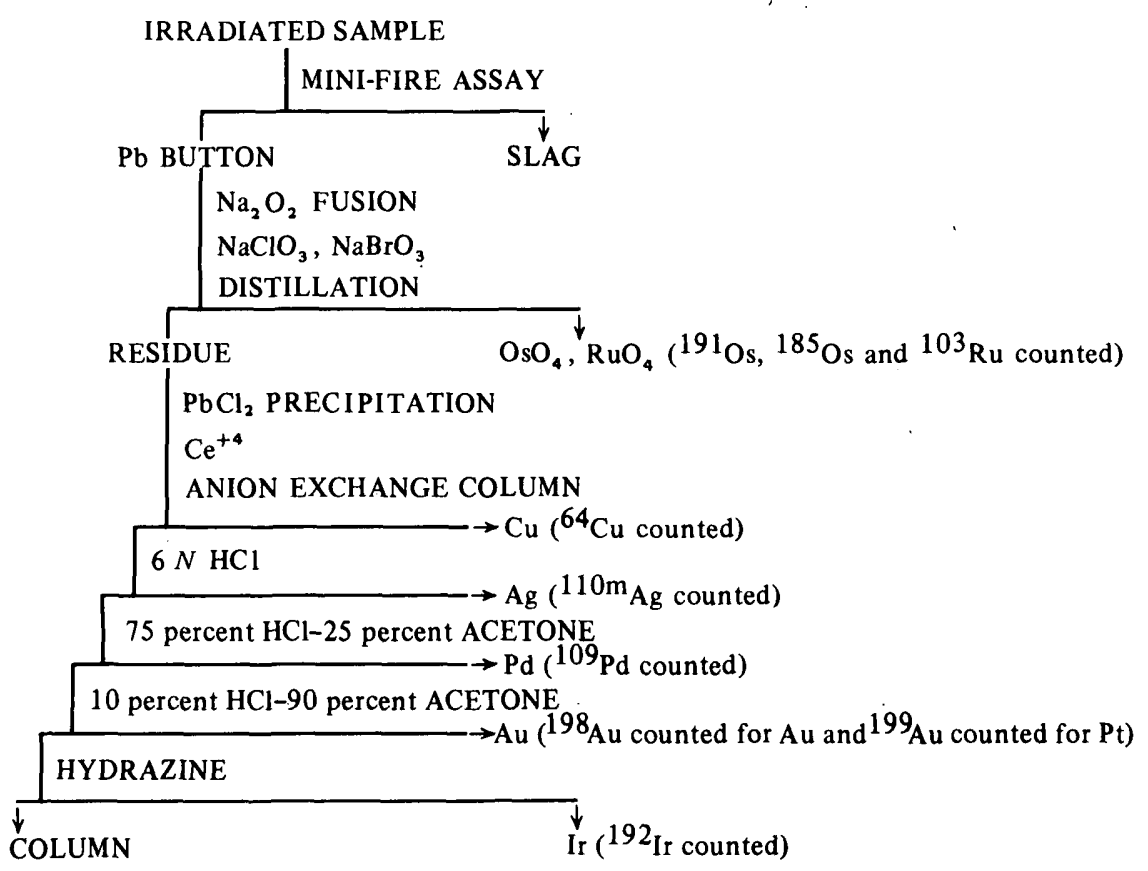

Figure 21. - Flow diagram for noble-metal and copper procedure. Modified from Millard and Bartel (1971).

\section{ACKNOWLEDGMENTS}

The authors are grateful to Adolph W. Haubert for performing the fire-assay analyses on many samples and instituting some of the steps to ease the processing of samples for fire assaying. Many thanks are also extended to L. A. Bradley, J. C. Hamilton, R. H. Heidel, H. G. Neiman, and M. W. Solt of the U.S. Geological Survey for the analyses of the various samples which contributed immeasurably to reducing the time in selecting the proper charge.

\section{REFERENCES CITED}

Agricola, Georgius, 1556, De re metallica, translated by H. C. Hoover and L. H. Hoover, 1950 [reprinted from The Mining Magazine, London, 1912]: New York, Dover Publications, $638 \mathrm{p}$.

Barnett, P. R., Huleatt, W. P., Rader, L. F., and Myers, A. T., 1955, Spectrographic determination of contamination of rock samples after grinding with alumina ceramic: Am. Jour. Sci., v. 253, no. 2, p. 121-124.

Bright, John, translator, 1965, Jeremiah, v. 21 of The Anchor Bible: Garden City, N. Y., Doubleday \& Co.

Bugbee, E. E., 1940, A textbook of fire assaying [3rd ed.]: New York, John Wiley \& Sons, $314 \mathrm{p}$. 
Clarke, F. W., and Hillebrand, W. F., 1897, Analyses of rocks, with a chapter on analytical methods, laboratory of the United States Geological Survey, 1880 to 1896: U.S. Geol. Survey Bull. 148, p. 9.

Covell, D. F., 1959, Determination of gamma-ray abundance directly from the total absorption peak: Anal. Chemistry, v. 31, p. 1785-1790.

Dahood, Mitchell, S. J., translator, 1966, Psalms I: 1-50, v. 16 of The Anchor Bible: Garden City, N.Y., Doubleday \& Co.

Emmons, S. F., 1886, Geology and mining industry of Leadville, Colorado: U.S. Geol. Survey Mon. 12, $770 \mathrm{p}$.

Erdtmann, G., 1972, Interference in neutron activation analytical determinations by uranium fission: Jour. Radioanalytical Chemistry, v. 10, p. $137-138$.

Forbes, R. J., 1950, Metallurgy in antiquity: Leiden, Netherlands, E. J. Brill, 489 p. 1964 , Studies in ancient technology, v. VIII, 2d revised ed.: Leiden, Netherlands, E. J. Brill, 295 p.

Greenland, L. P., Rowe, J. J., and Dinnin, J. I., 1971, Application of triple coincidence counting and of fire-assay separation to the neutron-activation determination of iridium: U.S. Geol. Survey Prof. Paper 750-B, p. B175-B179.

Grimaldi, F. S., and Schnepfe, M. M., 1970, Determination of iridium in mafic rocks by atomic absorption: Talanta, v. 17, p. $617-621$.

Haffty, Joseph, and Riley, L. B., 1968. Determination of palladium, platinum, and rhodium in geologic materials by fire assay and emission spectrography: Talanta, v. 15 , p. $111-117$.

1971, Suggested method for spectrochemical analysis of geologic materials by the fire-assay preconcentration-intermittent d-c arc technique, in Methods for emission spectrochemical analysis, 6th ed.: Am. Soc. Testing and Materials, p. 1027-1031.

Hillebrand, W. F., and Allen, E. T., 1905, Comparison of a wet and crucible-fire methods for the assay of gold telluride ores: U.S. Geol. Survey Bull. 253, $30 \mathrm{p}$.

Huffman, Claude, Jr., Mensik, J. D., Rader, L. F., 1966, Determination of silver in mineralized rocks by atomic-absorption spectrophotometry: U.S. Geol. Survey Prof. Paper 550-B, p. B189-B191.

Huffman, Claude, Jr., Mensik, J. D., and Riley, L. B., 1967, Determination of gold in geologic materials by solvent extraction and atomic-absorption spectrometry: U.S. Geol. Survey Circ. 544, 6 p.

Koda, Y., 1970, Determination of radioruthenium using a polyethylene film: Jour. Radioanalytical Chemistry, v. 6, p. $345-357$.

Millard, H. T., Jr., and Bartel, A. J., 1971, A neutron activation analysis procedure for the determination of the noble metals in geological samples, in $\mathrm{A}$. O. Brunfelt and E. O. Steinnes, eds., Activation analysis in geochemistry and cosmochemistry NATO Advanced Study Inst., Kjeller, Norway, Sept. 7-12, 1970, Proc.: OsloBergen-Tromso, Norway, Universitetsforlaget, p. 353-358.

Moreland, John, and Myers, A. T., 1973, Notes on use and maintenance of vertical pulverizers for geologic materials: U.S. Geol. Survey open-file report, 6 p.

Myers, A. T., and Havens, R. G., 1970, Spectrochemistry applied to geology and geochemistry by the U.S. Geological Survey in the Rocky Mountain region, in Proceedings of the second seminar on geochemical prospecting methods and techniques, Ceylon, 1970: U.N. ECAFE Mineral Resources Devel. Ser. 38, p. 286 -291.

Rowe, J. J., 1973, Determination of gold in phosphates by activation analysis using epithermal neutrons: U.S. Geol. Survey, Jour. Research, v. 1, no. 1, p. 79-80.

Rowe, J. J., and Simon, F. O., 1968, The determination of gold in geologic materials by neutron-activation analysis using fire assay for the radiochemical separations: U.S. Geol. Survey Circ. 599, 4 p. 
1971, Determination of platinum and palladium in geologic materials by neutron-activation analysis after fire-assay preconcentration: Talanta, v. 18, p. $121-125$.

Schnepfe, M. M., and Grimaldi, F. S., 1969, Determination of palladium and platinum by atomic absorption: Talanta, v. 16, p. 591-595.

Shepard, O. C., and Dietrich, W. F., 1940, Fire assaying, 1st ed.: New York, McGrawHill, $277 \mathrm{p}$.

Wertime, T. A., 1973, The beginnings of metallurgy; a new look: Science, v. 182, no. 4115 , p. $875-887$. 